\title{
Modulation of $\mathrm{T}$ cell activation by localized $\mathrm{K}+$ accumulation at the immunological synapse - a mathematical model
}

\author{
Geoffrey V. Martin ${ }^{\dagger}$, Yeoheung Yun ${ }^{\ddagger},{ }^{*}$, and Laura Conforti ${ }^{\dagger,}$ \\ tDepartment of Internal Medicine, Division of Nephrology, University of Cincinnati, Cincinnati \\ Ohio \\ ¥Department of Biomedical Engineering, North Carolina A\&T State University, Greensboro, North \\ Carolina
}

\begin{abstract}
The response of $\mathrm{T}$ cells to antigens ( $\mathrm{T}$ cell activation) is marked by an increase in intracellular $\mathrm{Ca}^{2+}$ levels. Voltage-gated and $\mathrm{Ca}^{2+}$-dependent $\mathrm{K}^{+}$channels control the membrane potential of human $\mathrm{T}$ cells and regulate $\mathrm{Ca}^{2+}$ influx. This regulation is dependent on proper accumulation of $\mathrm{K}^{+}$channels at the immunological synapse (IS) a signaling zone that forms between a $\mathrm{T}$ cell and antigen presenting cell. It is believed that the IS provides a site for regulation of the activation response and that $\mathrm{K}^{+}$channel inhibition occurs at the IS, but the underlying mechanisms are unknown. A mathematical model was developed to test whether $\mathrm{K}^{+}$efflux through $\mathrm{K}^{+}$channels leads to an accumulation of $\mathrm{K}^{+}$in the IS cleft, ultimately reducing $\mathrm{K}^{+}$channel function and intracellular $\mathrm{Ca}^{2+}$ concentration $\left(\left[\mathrm{Ca}^{2+}\right]_{\mathrm{i}}\right)$. Simulations were conducted in models of resting and activated $\mathrm{T}$ cell subsets, which express different levels of $\mathrm{K}^{+}$channels, by varying the $\mathrm{K}^{+}$diffusion constant and the spatial localization of $\mathrm{K}^{+}$channels at the IS. $\mathrm{K}^{+}$accumulation in the IS cleft was calculated to increase $\mathrm{K}^{+}$concentration $\left(\left[\mathrm{K}^{+}\right]\right.$) from its normal value of $5.0 \mathrm{mM}$ to $5.2-10.0 \mathrm{mM}$. Including $\mathrm{K}^{+}$accumulation in the model of the IS reduced calculated $\mathrm{K}^{+}$current by $1-12 \%$ and consequently, reduced calculated $\left[\mathrm{Ca}^{2+}\right]_{\mathrm{i}}$ by $1-28 \%$. Significant reductions in $\mathrm{K}^{+}$current and $\left[\mathrm{Ca}^{2+}\right]_{\mathrm{i}}$ only occurred in activated $\mathrm{T}$ cell simulations when most $\mathrm{K}^{+}$channels were centrally clustered at the IS. The results presented show that the localization of $\mathrm{K}^{+}$channels at the IS can produce a rise in $\left[\mathrm{K}^{+}\right]$in the IS cleft and lead to a substantial decrease in $\mathrm{K}^{+}$currents and $\left[\mathrm{Ca}^{2+}\right]_{\mathrm{i}}$ in activated $\mathrm{T}$ cells thus providing a feedback inhibitory mechanism during $\mathrm{T}$ cell activation.
\end{abstract}

\section{Keywords}

$\mathrm{T}$ cell activation; $\mathrm{K}^{+}$channels; immunological synapse; mathematical model; $\mathrm{K}^{+}$diffusion

\section{Introduction}

T lymphocyte activation is initiated by physical contact with an antigen presenting cell (APC) such as a dendritic or a B cell. Binding of the T cell receptor (TCR) to the antigen presented on the APC surface leads to cell polarization in which certain plasma membrane/ cytoplasmic proteins and intracellular organelles accumulate at the area of the $\mathrm{T}$ cell in contact with the APC forming the immunological synapse (IS) (Krummel and Cahalan, 2010). This is a highly organized signaling zone important in regulating the $\mathrm{T}$ cell activation

\footnotetext{
(C) 2012 Elsevier Ltd. All rights reserved.

Corresponding author: Laura Conforti, Department of Internal medicine, 231 A. Sabin Way, University of Cincinnati, Cincinnati, $\mathrm{OH}$ 45267-0585, Phone \# (513) 558-6009, Fax \# (513) 558-4309, laura.conforti@uc.edu.

Y-H Y and LC contributed equally
} 
response, including $\mathrm{Ca}^{2+}$ entry into the cell (Kummerow et al., 2009; Mossman et al., 2005; Quintana et al., 2005). A rise in intracellular $\mathrm{Ca}^{2+}$ levels $\left(\left[\mathrm{Ca}^{2+}\right]_{\mathrm{i}}\right)$ has been shown to follow immediately after APC stimulation and it is essential for activation of transcription factors and mitogenesis. Although $\mathrm{Ca}^{2+}$ plays such an important role in the $\mathrm{T}$ cell activation process, the mechanisms regulating $\mathrm{Ca}^{2+}$ signaling upon formation of the IS are not fully understood.

$\mathrm{Ca}^{2+}$ signaling in $\mathrm{T}$ cells is generated by $\mathrm{Ca}^{2+}$ influx through $\mathrm{Ca}^{2+}$ release activated $\mathrm{Ca}^{2+}$ (CRAC) channels (Cahalan and Chandy, 2009; Kummerow et al., 2009). CRAC channels are activated by depletion of the endoplasmic reticulum (ER) $\mathrm{Ca}^{2+}$ store, which is triggered upon T cell receptor (TCR) stimulation. Briefly, TCR stimulation leads to the release of $\mathrm{Ca}^{2+}$ from the ER via phospholipase $\mathrm{C} \gamma$ (PLC- $\gamma$ ) activation and production of inositol-3phosphate (IP3). Once ER $\mathrm{Ca}^{2+}$ stores are sufficiently depleted, stromal interaction molecule 1 (STIM1) in the ER moves into proximity to, and activates, Orai1 (a pore-forming subunit of the CRAC channel) and $\mathrm{Ca}^{2+}$ influx begins (Cahalan and Chandy, 2009). As $\mathrm{Ca}^{2+}$ enters the cell the membrane potential depolarizes, which in turn reduces CRAC current and limits $\mathrm{Ca}^{2+}$ entry. To counteract the cell depolarization and allow an increase in $\left[\mathrm{Ca}^{2+}\right]_{\mathrm{i}}$ of the appropriate magnitude and duration necessary for $\mathrm{T}$ cell activation, $\mathrm{K}^{+}$channels $(\mathrm{Kv} 1.3$ and $\mathrm{KCa} 3.1)$ open allowing $\mathrm{K}^{+}$efflux. Kv1.3 channels are voltage dependent and are activated by membrane depolarization while $\mathrm{KCa} 3.1$ channels are activated by an increase in $\left[\mathrm{Ca}^{2+}\right]_{\mathrm{i}}$. $\mathrm{K}^{+}$channels are differentially expressed in $\mathrm{T}$ cell subsets at different activation states with $\mathrm{Kv} 1.3$ being the predominant $\mathrm{K}^{+}$conductance in human resting $\mathrm{T}$ cells ( $\mathrm{rT}$ ) and activated effector memory $\left(\mathrm{a} \mathrm{T}_{\mathrm{EM}}\right.$ ) cells while $\mathrm{KCa} 3.1$ channels are up-regulated in activated naïve and central memory $\left(\mathrm{aT}_{\mathrm{CM}}\right.$ ) cells (Cahalan and Chandy, 2009; Koo et al., 1997). Although $\mathrm{K}^{+}$channels have been implicated in the etiology and progression of various diseases, their regulation during the activation process is not fully understood.

It has been recently reported that CRAC channels accumulate at the IS producing a localized increase in $\left[\mathrm{Ca}^{2+}\right]_{\mathrm{i}}$ (Lioudyno et al., 2008). Interestingly, $\mathrm{K}^{+}$channels also accumulate at the IS and this localization has been shown to be important in regulating $\mathrm{Ca}^{2+}$ signaling (Nicolaou et al., 2007a; Nicolaou et al., 2009; Nicolaou et al., 2007b; Nicolaou et al., 2010; Panyi et al., 2004b; Panyi et al., 2003). Defects in Kv1.3 localization in the IS have been associated with altered $\mathrm{Ca}^{2+}$ signaling in systemic lupus erythematosus (SLE) (Nicolaou et al., 2007b; Nicolaou et al., 2010). Furthermore, blockade of Kv1.3 compartmentalization into the IS has been shown to lead to an exaggerated $\mathrm{Ca}^{2+}$ response, suggesting that $\mathrm{Kv} 1.3$ activity is inhibited at the IS (Nicolaou et al., 2010). It is thus believed that the IS may constitute a site of $\mathrm{K}^{+}$channel modulation.

The exact mechanisms regulating $\mathrm{K}^{+}$channel activity at the IS are currently not known, but one theory is that the localization of $\mathrm{K}^{+}$channels at the IS can lead to efflux of $\mathrm{K}^{+}$and its accumulation in the narrow synaptic cleft (the extracellular space between $\mathrm{T}$ cell and APC) (Cahalan and Chandy, 2009; Kummerow et al., 2009). The localized increased in extracellular $\mathrm{K}^{+}$concentration ultimately reduces the driving force for $\mathrm{K}^{+}$efflux through $\mathrm{K}^{+}$ channels at the IS. Similar mechanisms involving localized accumulation (or depletion) of ions in the synaptic clefts have also been suggested to provide regulatory signaling pathways in neurons (Borst and Sakmann, 1999; Egelman and Montague, 1999; Kargacin, 1994; Rusakov and Fine, 2003; Vassilev et al., 1997). The purpose of the current study was to estimate whether accumulation of $\mathrm{K}^{+}$can indeed occur in immune cells and account for changes in $\left[\mathrm{Ca}^{2+}\right]_{i}$. Since, to our knowledge, experimental methods measuring actual $\mathrm{K}^{+}$ concentrations in the extremely small IS cleft are currently unavailable, this study was performed using mathematical models to simulate the $\mathrm{K}^{+}$accumulation in the IS cleft and to determine how this accumulation affects $\left[\mathrm{Ca}^{2+}\right]_{\mathrm{i}}$. 


\section{Methods}

Various simplifications and assumptions were made to allow simulating $\mathrm{K}^{+}$diffusion in the IS cleft and its effect on T cell currents. Descriptions of all parameter values used in the model are summarized in Table I. All simulations were performed with MATLAB (The MathWorks, Natick, MA).

\subsection{T cell Type}

The specific $\mathrm{T}$ cell types we modeled were a human resting $\mathrm{T}$ cell (rT), an activated central memory $\mathrm{T}$ cell $\left(\mathrm{aT}_{\mathrm{CM}}\right)$, and an activated effector memory $\mathrm{T}$ cell $\left(\mathrm{aT} \mathrm{T}_{\mathrm{EM}}\right)$. These cells express vastly different amounts of $\mathrm{Kv} 1.3$ and $\mathrm{KCa} 3.1$ channels on their cell membranes as summarized in Table II. In particular, the rT cell expresses a moderate level of Kv1.3 channels and low $\mathrm{KCa} 3.1$, the $\mathrm{aT}_{\mathrm{CM}}$ cell expresses a moderate level of $\mathrm{Kv} 1.3$ and moderate $\mathrm{KCa} 3.1$, and $\mathrm{aT}_{\mathrm{EM}}$ cells express a high number of $\mathrm{Kv} 1.3$ channels and low amounts of $\mathrm{KCa} 3.1$ (Wulff et al., 2003). Other possible sources/sinks of $\mathrm{K}^{+}$at the IS such as $\mathrm{K}^{+}$ channels on the APC and $\mathrm{Na}^{+}-\mathrm{K}^{+}$exchanger were neglected in our models to emphasize the specific role of $\mathrm{Kv} 1.3$ and $\mathrm{KCa} 3.1$ on the $\mathrm{T}$ cell and because the contribution other channels/ pumps on $\mathrm{K}^{+}$flux is negligible compared to that of $\mathrm{Kv} 1.3$ and $\mathrm{KCa} 3.1$ current. In essence $\mathrm{K}^{+}$entry into the IS cleft was modeled to have occurred only from Kv1.3 and $\mathrm{KCa} 3.1$ channels located on the T cell membrane.

\subsection{Immunological Synapse}

The IS modeled is a mature synapse with the characteristic bull's eye (supramolecular activation cluster, SMAC) configuration with a central core of TCR (cSMAC) surrounded by a ring of the adhesion protein lymphocyte function-associated antigen 1 (LFA-1) (pSMAC) and an outer ring of F actin (dSMAC) (Fig. 1A) (Cemerski and Shaw, 2006; Freiberg et al., 2002; Monks et al., 1998). The studies on ion channel distribution in the IS have indicated that Kv1.3 and KCa3.1 channels colocalize with the CD3-TCR complex in the cSMAC, (Fig. 1, A and B) and at least $50 \%$ of total Kv1.3 and KCa3.1 channels migrate to the IS upon T cell-APC interaction (Dustin and Chan, 2000; Nicolaou et al., 2007a; Nicolaou et al., 2009; Panyi et al., 2004b; Panyi et al., 2003). Hence, our model performed simulations with between 50 and $90 \%$ of $\mathrm{K}^{+}$channels aggregated at the IS, and the distribution of these channels at the IS varied from random to a central clustering. The dSMAC was not included in our model as we anticipate little $\mathrm{K}^{+}$channel aggregation at this site.

\subsection{Immunological Synaptic Cleft}

The IS cleft was modeled as a cylinder between the T cell and APC (Fig. 1, A and B). The T cell and APC membranes existed at the two faces (top and bottom) of the cylinder, while the rest of the cylinder was continuous with the normal extracellular space surrounding the cell membrane outside the IS (Fig. 1B). This normal extracellular space was modeled as an aqueous solution of $\mathrm{K}^{+}$concentration $\left(\left[\mathrm{K}^{+}\right]\right)=5 \mathrm{mM}$ to approximate normal physiological extracellular fluid. The specific dimensions of the IS cleft cylinder were defined from experimental studies on the geometry of the T cell-APC contact site (Anton van der Merwe et al., 2000; Cahalan and Chandy, 2009; Dustin and Chan, 2000). In our models the distance between the T cell and APC at the IS was $20 \mathrm{~nm}$, the radius of the entire IS cleft cylinder $1.78 \mu \mathrm{m}$, and the cSMAC radius to be $0.89 \mu \mathrm{m}$. A radius of $1.78 \mu \mathrm{m}$ gives a $\mathrm{T}$ cell surface area at the c-pSMAC of $10 \mu \mathrm{m}^{2}$, which is between $1-10 \%$ of the total T cell surface area (approximately $100 \mu \mathrm{m}^{2}$ and $1000 \mu \mathrm{m}^{2}$ in resting and activated T cells, respectively) (Grakoui et al., 1999). 


\subsection{Equivalent Circuit of T cell Membrane}

The $\mathrm{T}$ cell membrane was modeled as a capacitor in parallel with ion channels as resistors and the driving force of the ions as voltage sources (Fig. 1C). This model is similar to how Hodgkin and Huxley modeled ion currents across neuronal membranes, and has been well established in studying the electrical properties of neurons (Hodgkin and Huxley, 1952). In the human $\mathrm{T}$ cell, however, a few modifications to the neuronal model need to be made to include the three dominant membrane currents; the $\mathrm{Ca}^{2+}$ current through CRAC and the $\mathrm{K}^{+}$ current through Kv1.3 and KCa3.1 (Cahalan and Chandy, 2009; Panyi et al., 2004a). The membrane potential of the $\mathrm{T}$ cell using this equivalent circuit can be defined as,

$$
C_{M} \frac{\partial V_{M}}{\partial t}=-\left(I_{C R A C}+I_{K v 1.3}+I_{K C a 3.1}\right)
$$

where $C_{M}$ is the capacitance of the cell membrane, $V_{M}$ is the cell membrane potential, $I_{C R A C}$ is current through CRAC channels, $I_{K v 1.3}$ is current through Kv1.3 channels, and $I_{K C a 3.1}$ is current through KCa3.1 channels. $\mathrm{Ca}^{2+}$ efflux through the plasma membrane $\mathrm{Ca}^{2+}$ ATPase (PMCA) was not included in Eq. (1) because it is an electroneutral pump (Thomas, 2009). $C_{M}$ values were obtained from experimental measurements of resting and activated T cells (Robbins et al., 2005; Wulff et al., 2003).

\section{$2.5 \mathrm{Ca}^{2+}$ Signaling}

As previously mentioned the main source of the $\mathrm{Ca}^{2+}$ rise observed in $\mathrm{T}$ cells is due to extracellular current through CRAC channels. Unfortunately, these channels have extremely small conductances, and quantifying the precise biophysical parameters of these channels (single channel conductance, number of CRAC channels of the T cell, etc.) in T cells has proved difficult (Prakriya and Lewis, 2003). Experiments studying CRAC current at physiological $\left[\mathrm{Ca}^{2+}\right]$ have relied upon artificially induced ER $\mathrm{Ca}^{2+}$ depletion in Jurkat $\mathrm{T}$ cells (a leukemic T cell line) or in activated T cells, which allows for the study of total cell CRAC current in response to various stimuli (changing membrane potential, external $\left[\mathrm{Ca}^{2+}\right]$, etc.). Using this data an empirical fit to CRAC current was obtained by

$$
I_{C R A C}=A\left(E_{C a}-V_{M}\right)+B
$$

where $E_{C a}$ is the Nernst potential for $\mathrm{Ca}^{2+}$ assumed to be $143 \mathrm{mV}\left(\left[\mathrm{Ca}^{2+}\right]_{\mathrm{i}}=50 \mathrm{nM},\left[\mathrm{Ca}^{2+}\right]_{\mathrm{o}}\right.$ $=2 \mathrm{mM}), V_{M}$ is the membrane potential from Eq. 1, and $A$ and $B$ are empirical linear parameters for $I_{C R A C}$ derived from fitting experimental data between $-80 \mathrm{mV}$ and $-30 \mathrm{mV}$. While CRAC currents do not follow a linear relationship for all membrane potentials, they can be closely approximated by a linear model in the range of $\mathrm{T}$ cell membrane potentials $(-80$ to $-30 \mathrm{mV}$ ) (Rader et al., 1996; Verheugen and Vijverberg, 1995; Verheugen et al., 1995). In our simulations the $A$ and $B$ parameter values for $\mathrm{aT}_{\mathrm{EM}}$ and $\mathrm{aT}_{\mathrm{CM}}$ cells were derived from $I_{C R A C}$ currents recorded in activated T cells and Jurkat cells (Lewis and Cahalan, 1989; Lioudyno et al., 2008; Zweifach and Lewis, 1993), but for rT cells they were extrapolated from the values for activated T cells. This was made necessary by the fact that, contrary to experiments in activated $\mathrm{T}$ cells, the recordings of $I_{C R A C}$ currents in resting $\mathrm{T}$ cells are done at $20 \mathrm{mM}$ extracellular $\left[\mathrm{Ca}^{2+}\right]$ and not at physiological extracellular $\left[\mathrm{Ca}^{2+}\right](2$ $\mathrm{mM}) . I_{C R A C}$ from rT cells was thus assumed to obey the same membrane potential relationship as Eq. (2), but the magnitudes of $A$ and $B$ were decreased from the $\mathrm{aT}_{\mathrm{EM}} / \mathrm{aT}_{\mathrm{CM}}$ values until the input of the corresponding $I_{C R A C}$ value gave $\left[\mathrm{Ca}^{2+}\right]_{\mathrm{i}}$ levels similar to those

Publisher's Disclaimer: This is a PDF file of an unedited manuscript that has been accepted for publication. As a service to our customers we are providing this early version of the manuscript. The manuscript will undergo copyediting, typesetting, and review of the resulting proof before it is published in its final citable form. Please note that during the production process errors may be discovered which could affect the content, and all legal disclaimers that apply to the journal pertain. 
reported in the literature for rT cells. Our $I_{C R A C}$ current value in rT cells was in fact able to produce peak $\left[\mathrm{Ca}^{2+}\right]_{i}$ values $(\sim 200-400 \mathrm{nM})$, steady state $\left[\mathrm{Ca}^{2+}\right]_{\mathrm{i}}$ values $(\sim 100-200 \mathrm{nM})$, and the rate of $\left[\mathrm{Ca}^{2+}\right]_{\mathrm{i}}$ rise $(\sim 10-20 \mathrm{nM} / \mathrm{s})$ similar to values observed experimentally in resting T cells (Lioudyno et al., 2008). CRAC channel inactivation was not considered in this model due of the complexity of the mechanisms regulating it (Hoth et al., 2000).

$\mathrm{Ca}^{2+}$ efflux was modeled to have only occurred via the PMCA. Some experiments have shown that the PMCA is the only source of $\mathrm{Ca}^{2+}$ efflux in $\mathrm{T}$ cells, while others have shown the existence of an additional $\mathrm{Na}^{+}-\mathrm{Ca}^{2+}$ exchanger on the $\mathrm{T}$ cell membrane (Donnadieu et al., 1992; Lewis, 2001). Regardless of whether a $\mathrm{Na}^{+}-\mathrm{Ca}^{2+}$ exchanger is present or not, the relatively low $\left[\mathrm{Ca}^{2+}\right]_{\mathrm{i}}$ concentrations observed in T cells $(\sim 50-1,000 \mathrm{nM})$ would stimulate primarily the PMCA as it is much more sensitive to low $\left[\mathrm{Ca}^{2+}\right]_{\mathrm{i}}$ than the $\mathrm{Na}^{+}-\mathrm{Ca}^{2+}$ exchanger (Vassilev et al., 1997). Additionally, a Michaelis-Menten equation defining PMCA $\mathrm{Ca}^{2+}$ efflux in T cells has been determined experimentally, and this PMCA pump has been shown to undergo modulation when exposed to increased $\left[\mathrm{Ca}^{2+}\right]_{\mathrm{i}}($ Lewis, 2001). Therefore we have defined PMCA $\mathrm{Ca}^{2+}$ efflux as

$$
P M C A_{\text {efflux }}=\frac{W_{\max }-U_{\max } e^{-k t}}{1+\left(\frac{K_{m}+U_{m} e^{-k t}}{\left[C a^{2+}\right]_{i}}\right)^{2}}
$$

where $W_{\max }$ is the modulated maximum PMCA flux, $U_{\max }$ is the adjustment of $W_{\max }$ for an unmodulated PMCA, $K_{m}$ is the modulated $\left[\mathrm{Ca}^{2+}\right]_{\mathrm{i}}$ at half of $W_{\max }, U_{m}$ is the adjustment to $K_{m}$ for the unmodulated state of the PMCA, and $k$ is the time constant of PMCA modulation. $W_{\max }, U_{\max }$ were varied in resting vs. activated $\mathrm{T}$ cells to resemble experimental $\mathrm{Ca}^{2+}$ responses, and $k, K_{m}$ and $U_{m}$ were obtained from PMCA experimental values (Lewis, 2001).

Using the CRAC current as the only source of $\mathrm{Ca}^{2+}$ influx and the PMCA as the only source of $\mathrm{Ca}^{2+}$ efflux from the cell, $\left[\mathrm{Ca}^{2+}\right]_{\mathrm{i}}$ could be determined by

$$
\frac{\partial\left[C a^{2+}\right]_{i}}{\partial t}=\frac{1}{\beta V}\left(\frac{I_{C R A C}}{2 F}-\frac{P M C A_{e f f l u x}}{N_{A}}\right)
$$

where $\beta$ is an intracellular buffer of $\mathrm{Ca}^{2+}, V$ is the volume of the T cell, $N_{A}$ is Avogadro's number, and $F$ is Faraday's constant (Donnadieu et al., 1992; Fomina et al., 2000). This equation ignores spatial heterogeneity of $\left[\mathrm{Ca}^{2+}\right]_{\mathrm{i}}$ and the other intracellular compartments that could play a role in $\mathrm{Ca}^{2+}$ signaling (mitochondria, $\mathrm{ER}$, etc), but it is able to model the global rise in $\mathrm{Ca}^{2+}$ similar to experimental data (Donnadieu et al., 1992; Lioudyno et al., 2008).

\section{$2.6 \mathrm{~K}^{+}$Currents}

$\mathrm{K}^{+}$current through Kv1.3 channels was described by a Hodgkin-Huxley equation

$$
I_{K v 1.3}=N_{K v 1.3} g_{K v 1.3} \zeta \varphi\left(E_{K}-V_{M}\right)
$$

where $I_{K v 1.3}$ is the $\mathrm{K}^{+}$current through $\mathrm{Kv} 1.3$ channels, $\mathrm{N}_{\mathrm{Kv} 1.3}$ is the number of $\mathrm{Kv} 1.3$ channels, $g_{K v 1.3}$ is the Kv1.3 single channel conductance, $\zeta$ is the activation parameter of $\mathrm{Kv} 1.3$ channels, $\varphi$ is the inactivation parameter, and $E_{K}$ is the $\mathrm{K}^{+}$reversal (Nernst) potential. The activation and inactivation gating parameters were defined by

$$
\frac{\partial \zeta}{\partial t}=\frac{\left(\zeta_{\infty}-\zeta\right)}{\tau_{a}}
$$




$$
\frac{\partial \varphi}{\partial t}=\frac{\left(\varphi_{\infty}-\varphi\right)}{\tau_{i}}
$$

where $\tau_{a}$ is the time constant of activation, $\tau_{i}$ is the time constant of inactivation, $\zeta_{\infty}$ is the steady state activation and $\varphi_{\infty}$ is the steady state inactivation of Kv1.3 channels. To determine $\tau_{a}$ and $\tau_{i}$, Eq. 5 was fit to experimental whole-cell Kv1.3 currents recorded in resting human $\mathrm{T}$ cells with no IS formation. The steady state parameters were obtained from literature and followed the Boltzmann equations (Cahalan et al., 1985; Hajdu et al., 2003; Nicolaou et al., 2007a; Toth et al., 2009)

$$
\begin{aligned}
\zeta_{\infty} & =\frac{1}{1+e^{-0.2 \cdot\left(V_{M}+35\right)}} \\
\varphi_{\infty} & =\frac{1}{1+e^{-0.12\left(V_{M}+63.5\right)}}
\end{aligned}
$$

Modulation of $\zeta_{\infty}$ with an increasing extracellular $\left[\mathrm{K}^{+}\right]$was also included in this model. This modulation increases the steady state activation of Kv1.3 channels in a linear fashion $\sim 4$-fold when extracellular $\left[\mathrm{K}^{+}\right]$increases from 4.5 to $155 \mathrm{mM}$ at $-70 \mathrm{mV}$ (Levy and Deutsch, 1996a; Levy and Deutsch, 1996b).

KCa3.1 current was defined by

$$
I_{\text {KСа3.1 }}=g_{\text {KСа3.1 }} N_{\text {KСа3.1 }} P_{o}\left(E_{K}-V_{M}\right)
$$

where $g_{K C a 3.1}$ is the single channel conductance through KCa3.1 channels, $N_{K C a 3.1}$ is the number of KCa3.1 channels, and $P_{o}$ is the open probability of KCa3.1 channels. Inactivation of KCa3.1 channels is negligible, therefore $P_{o}$ was modeled as (Grissmer et al., 1993)

$$
P_{o}=\frac{1}{1+\left(\frac{K_{C a}}{\left[\mathrm{Ca}^{2+}\right]_{i}}\right)^{3}}
$$

where $K_{C a}$ is $\left[\mathrm{Ca}^{2+}\right]_{\mathrm{i}}$ at half maximum $\mathrm{KCa} 3.1$ activation.

To determine whole cell $\mathrm{K}^{+}$current $\left(I_{K}\right)$ the current through the $\mathrm{K}^{+}$channels outside the IS $\left(10 \%-50 \%\right.$ of the total channels) was added to current through $\mathrm{K}^{+}$channels at the IS (50$90 \%$ of total channels). $\mathrm{K}^{+}$currents outside the IS were calculated in the same manner and with the same variable values as IS $\mathrm{K}^{+}$channels except extracellular $\mathrm{K}^{+}$was equal to $5 \mathrm{mM}$ at all times. Ultimately, the difference in $\mathrm{K}^{+}$currents at the IS compared to the $\mathrm{K}^{+}$current throughout the rest of the cell was mediated through changes in $E_{K}$ and thus the driving force for $\mathrm{K}^{+}$.

\subsection{Diffusion Kinetics}

Since the IS cylindrical cleft is open to the extracellular space, free diffusion of $\mathrm{K}^{+}$between the IS cleft and the extracellular space could occur. This free diffusion occurs only at the cleft-extracellular junction and not across the T cell and APC membranes as their hydrophobic properties act as barriers to free diffusion of charged ions. To model how $\left[\mathrm{K}^{+}\right]$ changes inside the IS cleft the following diffusion equation was used 


$$
\frac{\partial\left[K^{+}\right]_{\text {cleft }}(x, y, z, t)}{\partial t}=D_{K} \nabla^{2}\left[K^{+}\right]_{\text {cleft }}(x, y, z, t)+J_{K}(x, y, z, t)
$$

where $t$ is time, $x, y$, and $z$ represent the spatial coordinates depicted in Fig. $1 \mathrm{~B},\left[\mathrm{~K}^{+}\right]_{\text {cleft }}$ is the concentration of $\mathrm{K}^{+}$in the synaptic cleft (from now on $\left[K^{+}\right]_{\text {cleft }}$ is assumed to be a function of $t, x, y, z), D_{K}$ is the $\mathrm{K}^{+}$diffusion constant inside the IS cleft, $\nabla^{2}$ is the Laplacian operator, and $J_{K}$ is the flux of $\mathrm{K}^{+}$entering the cleft due to $\mathrm{Kv} 1.3$ and $\mathrm{KCa} 3.1$ current at the IS. Individual $\mathrm{K}^{+}$channels located at the IS which comprised $J_{K}$ were assumed to be point sources of $\mathrm{K}^{+}$flux at the $\mathrm{T}$ cell membrane.

The boundary conditions defined for Eq. 12 were

$$
\begin{gathered}
\text { Boundary Condition } 1: \frac{\partial\left[K^{+}\right]_{\text {cleft }}}{\partial z}=0 \text { at } z=0,30 \mathrm{~nm} \\
\text { Boundary Condition } 2:\left[K^{+}\right]_{\text {cleft }}=5 \mathrm{mM} \text { at } x=y=1.78 \mu \mathrm{m} \\
\text { Initial Condition: }\left[\mathrm{K}^{+}\right]_{\text {cleft }}=5 \mathrm{mM} \text { at } t \leq 0
\end{gathered}
$$

where Boundary Condition 1 represented the plasma membranes of the T cell and APC as reflecting diffusion-limiting barriers to $\mathrm{K}^{+}$movement and Boundary Condition 2 represented the edges of the IS cleft in contact with the $5 \mathrm{mM}\left[\mathrm{K}^{+}\right]$solution outside the IS cleft and the Initial Condition represented the IS cleft as normal extracellular space $\left(\left[\mathrm{K}^{+}\right]=5 \mathrm{mM}\right)$ prior to $\mathrm{K}^{+}$accumulation from $\mathrm{K}^{+}$channels. These boundary and initial conditions were held constant throughout all the different model simulations while $D_{K}$ and $J_{K}$ in Eq. 12 were allowed to vary to study the effects different $\mathrm{K}^{+}$diffusion constants and $\mathrm{K}^{+}$fluxes would have on $\mathrm{K}^{+}$accumulation. To solve Eq. 12 the model was reduced to a system of ordinary differential equations (ODE's) using a finite difference discretization of spatial derivatives while leaving time as a continuous variable. Solutions were obtained using a MATLAB ODE solver that is able to take variable time steps on the order of $10^{-19} \mathrm{~s}$, satisfying any stability conditions of this finite difference method.

A potential problem with Eq. 12 is that it only takes into account diffusion due to concentration differences and not due to charge buildup. This assumption was deemed appropriate because the $\left[\mathrm{K}^{+}\right]$differences within the IS cleft (see Results) were no greater than $0.01 \mathrm{mM} / \mathrm{nm}$ in any direction, and ion exchanges in/out of the IS cleft $\left(\mathrm{Ca}^{2+}\right.$ into the cell, $\mathrm{Cl}^{-}$out of the cell) or the movement of other ions from the extracellular solution would counter $\mathrm{K}^{+}$charge accumulation. The electric field term that would have been added to the diffusion equation has a logarithmic dependence on concentration differences similar to a Nernst potential (i.e. proportional to $\log \left(\left[\mathrm{K}^{+}\right]_{\text {in one volume }} /\left[\mathrm{K}^{+}\right]_{\text {in adjacent volume }}\right.$ ) (Palti et al., 1979). Therefore the small concentration differences would produce an electric field term with a $\log (\sim 1)=0$. (For comparison across a cell membrane the $\left[\mathrm{K}^{+}\right]$has a difference of 135 $\mathrm{mM}$ over $10 \mathrm{~nm}$, creating significant electric field effects). Hence charge build up due to $\mathrm{K}^{+}$ accumulation in the IS cleft does not appear to play a significant role in $\mathrm{K}^{+}$diffusion, and was neglected in our model.

\subsection{Diffusion Constant in the IS Cleft}

To determine the appropriate $D_{K}$ in the IS cleft additional limitations had to be considered since the synaptic cleft is in fact not a free solution. Specifically, the geometry of the cleft with $\mathrm{T}$ and APC membranes constituting barriers to $\mathrm{K}^{+}$diffusion at the top and bottom of 
cylinder and the presence of a network of proteins linking the APC and T cell could limit the speed at which $\mathrm{K}^{+}$moves, thus lowering $D_{K}$ compared to its free solution value of $\sim 2,000$ $\mu \mathrm{m}^{2} / \mathrm{s}$ (Treherne et al., 1970). Random walk simulations of $1,000 \mathrm{~K}^{+}$ions randomly moving from the center of a rectangular box with dimensions similar to the IS cleft $\left(10 \mu \mathrm{m}^{2}\right.$ by 30 $\mathrm{nm})$ were performed. T cell and APC membranes and intercellular proteins were modeled as reflecting barriers to diffusion with intercellular protein complexes represented as cylinders extending from the T cell to the APC membrane. $D_{K}$ was determined from these simulations by

$$
D_{K}=\frac{d^{2}}{6 t}
$$

where $d$ is the distance from the center of the box and $t$ is the amount of time that has passed during the simulations. These random walks used 10,000 time steps of $1 \mathrm{~ns}$. The distance moved by the $\mathrm{K}^{+}$ions in one nanosecond was determined by modeling the motion of the particles in free solution then adjusting the distance per step to match the experimental result of $2,000 \mu \mathrm{m}^{2} / \mathrm{s}$.

\section{Results}

\section{$3.1 \mathrm{~K}^{+}$Diffusion Constant}

The random walk simulations $(\mathrm{n}=15)$ without any proteins in the IS cleft yielded a $D_{K}$ of $1,130-1,470 \mu \mathrm{m}^{2} / \mathrm{s}$ (average $\left.=1,320 \mu \mathrm{m}^{2} / \mathrm{s}\right)$. These values are most likely an overestimation of the actual $D_{K}$ in the IS. Although there are no measurements of ion diffusion in the IS, previous studies have measured the diffusion constants of ions in the extracellular space of the brain to be reduced 60\% (Sykova and Nicholson, 2008), while other studies have measured intracellular diffusion of ions to be reduced 200-300\% (Zaniboni et al., 2003). We have thus recreated a microenvironment more similar to the synaptic cleft by adding proteins that occupy this space and connect the T cell to the APC. The addition of IS cleft proteins to the random walk simulations yielded a $D_{K}$ that decreased with increasing intercellular protein density as depicted in Fig. 2. The results in Fig. 2 are reported in terms of IS cleft volume occupied by intercellular proteins, but could have been reported in terms of any intercellular protein density like LFA-1/ICAM or TCR/MHC complexes. The x-axis in Fig. 2 can be converted to any intercellular protein density if the volume of the intercellular protein complex is known. For reference, if the LFA-1/ICAM complex is assumed to have volume of $40 \mathrm{~nm}$ by $400 \mathrm{~nm}^{2}$, then a density of $1000 \mu \mathrm{m}^{-2}$ (experimental measurements of ICAM density at the IS are 200-1200 $\mu^{-2}$ ) corresponds to a fraction of IS cleft volume occupied of 0.4 (Galush et al., 2008; Willemsen et al., 1998). The random walk simulations also predicted a diffusion constant of zero when the total volume in the IS cleft occupied by proteins was $50 \%$ or greater, which is consistent with the percolation limit for random movements in a 2D lattice (Kesten, 1980). Due to the results from these simulations and the estimated protein density at the IS (see above), $D_{K}$ was assumed to be either 250 or 500 $\mu \mathrm{m}^{2} / \mathrm{s}$ in subsequent simulations.

\subsection{Accumulation of $\mathrm{K}^{+}$in the IS Cleft}

The calculated $\left[\mathrm{K}^{+}\right]_{\text {cleft }}$ for an a $\mathrm{T}_{\mathrm{CM}}$ cell early upon contact with an APC and its correlation with the synaptic space are reported in Figure 3A. This simulation was conducted with a $D_{K}$ of $500 \mathrm{um}^{2} / \mathrm{s}$ and $90 \% \mathrm{~K}^{+}$channels localized centrally in the cSMAC of the IS. Furthermore, like in subsequent simulations, we assumed the following initial conditions: the $\left[K^{+}\right]_{\text {cleft }}$ was assumed to be $5 \mathrm{mM},\left[\mathrm{Ca}^{2+}\right]_{\mathrm{i}}$ was assumed to be $50 \mathrm{nM}, V_{M}$ was assumed to be $-60 \mathrm{mV}$, CRAC channels were assumed to open at $t=0$ in response to $\mathrm{T}$ cell stimulation by an APC, and $\mathrm{K}^{+}$channels were assumed to be located at the IS at the initial 
condition of $t=0$. This simulation showed that $\mathrm{K}^{+}$distributes rapidly and uniformly within the IS cleft, and peak $\left[\mathrm{K}^{+}\right]_{\text {cleft }}$ is reached within $30 \mathrm{~ms}$ (with significant accumulation usually in 10-20 ms) from the time that CRAC channels open $(t=0)$. The $\left[K^{+}\right]_{\text {cleft }}$ was maximal at the center of the IS and it decreased rapidly with increasing distance from the IS center, which is expected since all $\mathrm{K}^{+}$channels are modeled to be located in the cSMAC. On the contrary, the $\left[\mathrm{K}^{+}\right]_{\text {cleft }}$ was independent of the distance from the T cell membrane $(z)$ which indicates that similar $\left[\mathrm{K}^{+}\right]$are reached almost instantly at the T and APC membranes. This latter result can be attributed to significantly faster diffusion of $\mathrm{K}^{+}$across the small distance between T cell and APC (20-100 nm) compared to the width of the IS $(1-2 \mu \mathrm{m})$. Results with a time course and spatial distribution similar to Fig. 3A were obtained for rT and $\mathrm{aT}_{\mathrm{EM}}$ cells with only the magnitude of $\mathrm{K}^{+}$accumulation varying between simulations (Fig. 3C).

$\mathrm{K}^{+}$accumulation was also much less when $\mathrm{K}^{+}$channels were uniformly distributed throughout the IS as opposed to being centrally clustered (Fig. 3B) or if only $50 \%$ of $\mathrm{K}^{+}$ channels were modeled at the IS (Fig. 3C). In simulations with $\mathrm{K}^{+}$channels uniformly distributed at the IS the maximum value of $\left[K^{+}\right]_{\text {cleft }}$ never rose above $6.5 \mathrm{mM}$ even with $D_{K}$ $=250 \mu \mathrm{m}^{2} / \mathrm{s}$ and $90 \% \mathrm{~K}^{+}$channel IS aggregation. If only $50 \%$ of $\mathrm{K}^{+}$channels were modeled at the IS, $\mathrm{K}^{+}$accumulation (i.e. $\left[\mathrm{K}^{+}\right]_{\text {cleft }}$ values above $5 \mathrm{mM}$ ) was reduced $55-65 \%$. The time when $\left[K^{+}\right]_{\text {cleft }}$ dissipated to its starting value of $5 \mathrm{mM}$ was also calculated when $D_{K}$ was $250 \mu \mathrm{m}^{2} / \mathrm{s}$, and regardless of $\left[K^{+}\right]_{\text {cleft }}($ range $5.2-10 \mathrm{mM}$ ) the time of dissipation was less than $30 \mathrm{~ms}$ (range $23-30 \mathrm{~ms}$ ).

\subsection{Time-dependent change in $\left[\mathrm{K}^{+}\right]_{\text {cleft }}$ and its impact on $\mathrm{K}^{+}$current, $\mathrm{V}_{\mathrm{M}}$ and $\left[\mathrm{Ca}^{2+}\right]_{\mathrm{i}}$}

The $\mathrm{K}^{+}$accumulation in the synaptic cleft is a dynamic process that depends not only on the number of $\mathrm{K}^{+}$channels in the cleft and their localization in the IS (see above), but also on the activity of the Kv1.3 and KCa3.1 channels. The activity of Kv1.3 and KCa3.1 channels depends on the $V_{M}$ and $\left[\mathrm{Ca}^{2+}\right]_{\mathrm{i}}$, respectively, and $\left[K^{+}\right]_{\text {cleft }}$ which determines $\mathrm{E}_{\mathrm{K}}$. The following simulations define the reciprocal influence of these time-dependent variables and predict the ultimate outcome of $\mathrm{K}^{+}$accumulation in the IS cleft on $\left[\mathrm{Ca}^{2+}\right]_{i}$ which is responsible for $\mathrm{T}$ cell activation (proliferation and cytokine release). Fig. 4 shows how $\left[K^{+}\right]_{\text {cleft }}$ (Fig. 4A), $I_{K}$ (Fig. 4B), $V_{M}$ (Fig. 4C), and $\left[\mathrm{Ca}^{2+}\right]_{\mathrm{i}}$ (Fig. 4D) vary with time after T cell stimulation. These time-dependent simulations were performed under three conditions: 1) no $\mathrm{K}^{+}$channel aggregation at the IS, 2) $\mathrm{K}^{+}$channel aggregation at the IS with $D_{K}=250$ $\mathrm{um}^{2} / \mathrm{s}$, and 3) $\mathrm{K}^{+}$channel aggregation at the IS with $\mathrm{D}_{\mathrm{K}}=500 \mathrm{um}^{2} / \mathrm{s}$. Simulations with IS $\mathrm{K}^{+}$ channel aggregation were performed assuming $90 \% \mathrm{~K}^{+}$channel aggregation in the cSMAC, and simulations without IS $\mathrm{K}^{+}$channel aggregation assumed $\mathrm{K}^{+}$channels were uniformly distributed on the $\mathrm{T}$ cell membrane after IS formation. By comparing simulations with $\mathrm{IS} \mathrm{K}^{+}$ channel aggregation vs. simulations without IS $\mathrm{K}^{+}$channel aggregation the effect of $\left[K^{+}\right]_{\text {cleft }}$ on $I_{K}, V_{M}$, and $\left[\mathrm{Ca}^{2+}\right]_{\mathrm{i}}$ could be appreciated.

Throughout all simulations with $\mathrm{K}^{+}$channel localization in the IS most of the $\left[\mathrm{K}^{+}\right]_{\text {cleft }}$ rise occurred during the first $30 \mathrm{~ms}$ (Fig. 3A), and $\left[\mathrm{K}^{+}\right]_{\text {cleft }}$ did not vary substantially for $\mathrm{t}>1 \mathrm{~s}$ except in a $\mathrm{T}_{\mathrm{CM}}$ cells (Fig. 4A). In aT $\mathrm{C}_{\mathrm{CM}}$ cells, which express $\mathrm{KCa} 3.1$ and $\mathrm{Kv} 1.3$ in the same number, the initial accumulation of $\mathrm{K}^{+}$in the cleft is followed by a transient decrease in $\left[\mathrm{K}^{+}\right]_{\text {cleft }}$ that occurs within $50 \mathrm{~s}$. This corresponds to the $\mathrm{Ca}^{2+}$ peak that develops early upon activation (Fig. 4D) and is due to the activation of KCa3.1 channels. Opening of KCa3.1 channels induces membrane hyperpolarization that decreases Kv1.3 channel activity with a net decrease in $\left[\mathrm{K}^{+}\right]_{\text {cleft }}$. In all simulations, $V_{M}$ (Fig. 4C) was least when $\left[\mathrm{Ca}^{2+}\right]_{\mathrm{i}}$ peaked and increased to a steady state value $(t>100 \mathrm{~s})$ with a time course similar to $\left[\mathrm{Ca}^{2+}\right]_{\mathrm{i}}$ signaling (Fig. 4D). In all simulation the $\left[\mathrm{Ca}^{2+}\right]_{\mathrm{i}}$ rise was biphasic with a peak between $10-40 \mathrm{~s}$ after CRAC channel opening which then decayed to a steady state $\mathrm{Ca}^{2+}$ level (Fig. 4D). 
Simulations of a $\mathrm{T}_{\mathrm{EM}}$ and $\mathrm{aT}_{\mathrm{CM}}$ cells had larger $\left[\mathrm{Ca}^{2+}\right]_{\mathrm{i}}$ compared to simulations of rT cells due to both an increased $\mathrm{Ca}^{2+}$ influx and increased Kv1.3 and KCa3.1 channel expression.

Comparisons between the simulations with $\mathrm{K}^{+}$channels accumulation in the IS and those without showed that accumulation of $\mathrm{K}^{+}$in the IS cleft resulted in significant changes in $I_{K}$, $V_{M}$ and $\left[\mathrm{Ca}^{2+}\right]_{i}$ only in $\mathrm{aT}_{\mathrm{CM}}$ and aT $\mathrm{T}_{\mathrm{EM}}$ cells where a 1.46-1.92 fold increase in $\left[\mathrm{K}^{+}\right]_{\text {cleft }}$ was associated with a 3-12\% decrease in $I_{K}$ and a 3-20\% change in $V_{M}$ throughout the duration of the simulation (Fig. 4A-C). Ultimately, in the simulation with IS $\mathrm{K}^{+}$channel aggregation peak $\left[\mathrm{Ca}^{2+}\right]_{\mathrm{i}}$ was reduce by $13-18 \%$ and $11-16 \%$ in $\mathrm{aT}_{\mathrm{CM}}$ and $\mathrm{aT}_{\mathrm{EM}}$ models, respectively (Fig. 4D), while the reduction in steady state $\left[\mathrm{Ca}^{2+}\right]_{\mathrm{i}}$ was $20-28 \%$ in aT $\mathrm{CM}_{\mathrm{CM}}$ cells and 6-9\% in aT $\mathrm{T}_{\mathrm{EM}}$ cells. The $\mathrm{Ca}^{2+}$ reduction paralleled the difference in $V_{M}$ between simulations as shown by the fact that $\mathrm{aT}_{\mathrm{CM}}$ simulations showed large differences in $V_{M}$ and $\left[\mathrm{Ca}^{2+}\right]_{\mathrm{i}}$ at $t>1 \mathrm{~s}$ while $\mathrm{aT}_{\mathrm{EM}}$ simulations only showed large differences in $V_{M}$ and $\left[\mathrm{Ca}^{2+}\right]_{\mathrm{i}}$ during peak $\left[\mathrm{Ca}^{2+}\right]_{\mathrm{i}}$. The rate of $\left[\mathrm{Ca}^{2+}\right]_{\mathrm{i}}$ rise was instead very similar between simulations with IS $\mathrm{K}^{+}$channel aggregation compared to simulations without $\mathrm{IS} \mathrm{K}^{+}$channel aggregation within each $\mathrm{T}$ cell type. In particular, the rate of $\left[\mathrm{Ca}^{2+}\right]_{\mathrm{i}}$ rise in resting $\mathrm{T}$ cells was $16.3 \mathrm{nM} / \mathrm{s}$ with IS $\mathrm{K}^{+}$channel aggregation and was $16.9 \mathrm{nM} / \mathrm{s}$ without IS $\mathrm{K}^{+}$channel aggregation, in $\mathrm{aT}_{\mathrm{CM}}$ cells was $24.5 \mathrm{nM} / \mathrm{s}$ with IS $\mathrm{K}^{+}$channel aggregation and $25.0 \mathrm{nM} / \mathrm{s}$ without IS $\mathrm{K}^{+}$ channel aggregation, and in aT $\mathrm{EM}_{\mathrm{EM}}$ cells was $22.6 \mathrm{nM} / \mathrm{s}$ with IS $\mathrm{K}^{+}$channel aggregation and $23.1 \mathrm{nM} / \mathrm{s}$ without IS $\mathrm{K}^{+}$channel aggregation.

Only simulations with $90 \% \mathrm{~K}^{+}$channel IS aggregation and central clustering of $\mathrm{K}^{+}$channels are depicted in Fig. 4 since simulations with $50 \% \mathrm{~K}^{+}$channel IS aggregation or a uniform IS distribution showed maximum differences in $\left[\mathrm{Ca}^{2+}\right]_{\mathrm{i}}$ due to IS cleft $\mathrm{K}^{+}$accumulation of $16 \%$ (data not shown). With $50 \% \mathrm{~K}^{+}$channel IS aggregation not only was $\left[K^{+}\right]_{\text {cleft }}$ reduced but there were also less channels affected by the rise in $\left[\mathrm{K}^{+}\right]_{\text {cleft }}$.

The simulations reported above utilized parameter values obtained from experiments conducted at room temperature. This was made necessary as most electrophysiological experiments are conducted at this temperature. However, because of well supported evidence that an increase in temperature to $37^{\circ} \mathrm{C}$ increased $\mathrm{Kv} 1.3$ conductance to $\sim 20 \mathrm{pS}$ (Pahapill and Schlichter, 1990), we ran the simulation with these parameter values and found that increasing Kv1.3 conductance does not change the \% differences in $V_{M}$ and $\left[\mathrm{Ca}^{2+}\right]_{\mathrm{i}}$ in simulations with IS $\mathrm{K}^{+}$channel aggregation vs. simulations without IS $\mathrm{K}^{+}$channel aggregation but only slightly changes the absolute values of $V_{M}$ and $\left[\mathrm{Ca}^{2+}\right]_{\mathrm{i}}$ (data not shown).

Overall, the result presented showed that accumulation of $\mathrm{K}^{+}$in the IS cleft resulted in changes in $V_{M}$ and $\left[\mathrm{Ca}^{2+}\right]_{\mathrm{i}}$ which depended on the magnitude of $\left[\mathrm{K}^{+}\right]_{\text {cleft }}$, the number of $\mathrm{K}^{+}$ channels at the IS and on the T cell type.

\section{Discussion}

The results presented show that the localization of $\mathrm{K}^{+}$channels at the IS can produce a rise in $\left[\mathrm{K}^{+}\right]$in the IS cleft and lead to a substantial decrease in $\mathrm{K}^{+}$currents and $\left[\mathrm{Ca}^{2+}\right]_{\mathrm{i}}$ in activated $\mathrm{T}$ cells. These results are consistent with finding obtained by theoretical modeling and in vitro experiments in neurons showing localized ion accumulation/depletion in neuronal synapses. However, to our knowledge, before this study there was neither in silico nor in vitro evidence that ion accumulation occurs at the IS. Our study shows that formation of an IS can create the spatial and structural conditions by which extracellular $\left[\mathrm{K}^{+}\right]$can inhibit $\mathrm{T}$ cell $\mathrm{Ca}^{2+}$ signaling and possibly provide a negative feedback signaling mechanism.

The data we provided showed that this effect is only achieved when certain conditions at the IS are met: a large percentage of total $\mathrm{K}^{+}$channels aggregate at the IS and these channels are 
located in the cSMAC. Without central clustering the model predicts that $\mathrm{K}^{+}$accumulation in the IS cleft is small. The reason for the precise spatial sorting of proteins at the IS into distinct domains has been the topic of many previous theoretical studies (Hori et al., 2002; Raychaudhuri et al., 2003; Weikl and Lipowsky, 2004). In particular, these theoretical studies have shown that close spatial clustering of TCR (either in microclusters or in the cSMAC) could allow for enhanced signaling either through serial MHC engagement or an increased chance of intracellular TCR phosphorylation, but there has still been debate over the active role of the cSMAC in T cell signaling (Burroughs et al., 2006; Cemerski et al., 2008; Dushek and Coombs, 2008). The result from our study, that central clustering of $\mathrm{K}^{+}$ channels at the IS is crucial to IS cleft $\mathrm{K}^{+}$accumulation and $\mathrm{Ca}^{2+}$ inhibition, provides an additional mechanism for signaling at the cSMAC. The central aggregation of proteins in the IS could provide a location for $\mathrm{K}^{+}$channel accumulation and a restricted diffusion environment, thus emphasizing an inhibition of $\mathrm{K}^{+}$and $\mathrm{Ca}^{2+}$ signaling. A central clustering of $\mathrm{K}^{+}$channels at the IS is supported by experimental studies showing that both KCa3.1 and Kv1.3 channels co-localize with CD3 at the center of a mature IS (Nicolaou et al., 2007a; Nicolaou et al., 2009; Panyi et al., 2003). The relationship between protein concentration, $\mathrm{K}^{+}$channel spatial sorting, and $\left[\mathrm{Ca}^{2+}\right]_{\mathrm{i}}$ could signal various features of IS composition to the $\mathrm{T}$ cell including the density/strength of MHC-TCR interactions or the overall stability of the IS through other intercellular protein complexes.

Interestingly, $\mathrm{K}^{+}$accumulation in the IS ultimately could have important functional consequences on activated $\mathrm{T}$ cells such as reduced $\mathrm{Ca}^{2+}$ influx. This is important as activated $\mathrm{T}$ cells are involved in the etiology and progression of various diseases including SLE. Our simulations implicates that without the normal $\mathrm{K}^{+}$channel inhibition caused by IS cleft $\mathrm{K}^{+}$accumulation, the $\mathrm{T}$ cell would be more prone to activation through excessive increased $\mathrm{Ca}^{2+}$ influx. A hyperactivation like this occurs in SLE. In these patients Kv1.3 channels localize to the IS for shorter times compared to normal individuals and the $\mathrm{Ca}^{2+}$ response is more sustained than in normal donors (Nicolaou et al., 2007b; Nicolaou et al., 2010). As shown by the results from these simulations, a difference in the spatial arrangement of $\mathrm{K}^{+}$channels at the IS can drastically influence $\mathrm{Kv} 1.3$ and $\mathrm{KCa} 3.1$ current inhibition, and the fast ms time scales of IS cleft $\mathrm{K}^{+}$dissipation mean that premature $\mathrm{K}^{+}$ channel movement out of the IS could terminate $\mathrm{K}^{+}$accumulation, $\mathrm{Kv} 1.3$ and $\mathrm{KCa} 3.1$ inhibition very quickly. This proposed mechanism explaining $\mathrm{K}^{+}$dysfunction in SLE patients fits well with experimental evidence that the biophysical characteristics of $\mathrm{K}^{+}$ current through Kv1.3 channels are not changed in this disease, only Kv1.3 localization, and emphasizes the crucial role $\left[\mathrm{K}^{+}\right]_{\text {cleft }}$ could have on $\mathrm{Ca}^{2+}$ signaling (Nicolaou et al., 2007b; Poulopoulou et al., 2008).

Similar effects could also occur at the APC membrane. The observation that the $\left[\mathrm{K}^{+}\right]_{\text {cleft }}$ was equal at the T cell and APC membrane at a given xy-distance from $\mathrm{K}^{+}$channels reflects that diffusion occurs very rapidly (in $\mathrm{ns}$ ) across the narrow $(30 \mathrm{~nm}$ ) cleft compared to diffusion in the xy-plane of the cleft $\left(10 \mu \mathrm{m}^{2}\right)$. This implies that ion channels in the IS on the APC membrane will experience the same extracellular $\left[\mathrm{K}^{+}\right]$as ion channels in the IS on the $\mathrm{T}$ cell membrane. The elevated $\left[\mathrm{K}^{+}\right]_{\text {cleft }}$ could then cause decreased $\mathrm{K}^{+}$efflux through APC $\mathrm{K}^{+}$channels located at the IS leading to APC depolarization. A similar bilateral effect has been shown to occur in neurons where $\mathrm{Ca}^{2+}$ depletion in the synaptic cleft results in reduction of $\mathrm{Ca}^{2+}$ currents both in the presynaptic or post-synaptic neurons (Borst and Sakmann, 1999).

Although direct experimental confirmation of changes in $\left[\mathrm{K}^{+}\right]$in the IS cleft has yet to be produced, other aspects of our simulation compare well with experimental data. We have previously reported that restricting Kv1.3 from entering the IS results in a increase in peak and steady state $\left[\mathrm{Ca}^{2+}\right]_{\mathrm{i}}$ of $\sim 1.8$ fold in Jurkat $\mathrm{T}$ cells (Nicolaou et al., 2009). These same 
experiments also showed very little difference in the rate of the $\left[\mathrm{Ca}^{2+}\right]_{\mathrm{i}}$ rise between experiments with Kv1.3 in the IS vs. when Kv1.3 was restricted from the IS. During our simulations without $\mathrm{K}^{+}$channel aggregation in the IS, peak $\left[\mathrm{Ca}^{2+}\right]_{\mathrm{i}}$ was increased $1.15-1.21$ fold in $\mathrm{aT}_{\mathrm{CM}}$ and $1.12-1.18$ fold in a $\mathrm{T}_{\mathrm{EM}}$ cells, and steady state $\left[\mathrm{Ca}^{2+}\right]_{\mathrm{i}}$ was increased $1.25-$ 1.38 in $\mathrm{aT}_{\mathrm{CM}}$ and 1.06-1.10 fold in a $\mathrm{T}_{\mathrm{EM}}$ cells compared to the $\mathrm{K}^{+}$channel IS aggregation model (Fig. 4). Furthermore, the rate of the $\mathrm{Ca}^{2+}$ rise predicted in our model was almost the same between simulations when $\mathrm{K}^{+}$channels were inside the IS vs. when they were not in the IS. While this model did not match exactly the conditions of the experiment (Jurkat vs. activated T cells and selective Kv1.3 restriction vs. total $\mathrm{K}^{+}$channel restriction), our results do show that under certain conditions IS cleft $\mathrm{K}^{+}$accumulation provides a plausible explanation for at least some of the reduced $\left[\mathrm{Ca}^{2+}\right]_{\mathrm{i}}$ observed experimentally.

Still, we cannot exclude that other factors regulate $\mathrm{K}^{+}$channel activity at the IS. These would be particularly relevant in conditions where little $\mathrm{K}^{+}$accumulation in the IS cleft may occur (e.g. rT cells and no central clustering). Another reason for altered $\mathrm{K}^{+}$channel function at the IS could be changes in channel protein phosphorylation. In particular, the IS contains many signaling molecules such as Lck, PKC $\theta$, and PKA which are known regulators of Kv1.3 channels (Bowlby et al., 1997; Cai and Douglass, 1993; Fadool, 1998; Holmes et al., 1996; Szigligeti et al., 2006). $\mathrm{K}^{+}$channel modification at the IS and IS cleft $\mathrm{K}^{+}$accumulation could also work synergistically to inhibit $\mathrm{K}^{+}$currents and $\left[\mathrm{Ca}^{2+}\right]_{\mathrm{i}}$, and modification of the present model could be made to incorporate these events and test model predictions against future experimental evidence.

While the model derived in this study has many strengths in predicting $\mathrm{T}$ cell membrane currents, membrane potential, and $\left[\mathrm{Ca}^{2+}\right]_{i}$, it does present with a few limitations. This model assumes all $\mathrm{K}^{+}$channels are in the IS as soon as CRAC channels open and that all CRAC channels open at once. In actuality $\mathrm{K}^{+}$channel migration takes seconds up to two minutes, and CRAC channel activation will depend on time course of $\mathrm{ER} \mathrm{Ca}^{2+}$ depletion (Luik et al., 2008; Nicolaou et al., 2007a; Nicolaou et al., 2009). Furthermore, this model did not incorporate extracellular or intracellular $\mathrm{Ca}^{2+}$ microdomains or other $\mathrm{Ca}^{2+}$ compartments. Similar to $\mathrm{K}^{+}$accumulation in the IS cleft, $\mathrm{Ca}^{2+}$ could have also been depleted from the cleft, lowering $\mathrm{Ca}^{2+}$ influx through CRAC channels. $\mathrm{Ca}^{2+}$ could also accumulate in intracellular microdomains adjacent to CRAC channels influencing CRAC, PMCA, and KCa3.1 activity (Bautista and Lewis, 2004). One reason the $\mathrm{Ca}^{2+}$ microdomains were ignored is because as shown from our $\mathrm{K}^{+}$modeling the spatial distribution of channels can have a drastic consequence on ion accumulation, and currently, experimental information regarding where in the IS $\mathrm{Ca}^{2+}$ influx / efflux is occurring is not available. Overall the goal of this paper was to investigate $\mathrm{K}^{+}$channel current's role on $\left[\mathrm{Ca}^{2+}\right]_{\mathrm{i}}$ during formation of an IS, and our simulations were able to model the global $\left[\mathrm{Ca}^{2+}\right]_{\mathrm{i}}$ comparable to experiments without considering the complexities of the ER, mitochondria, etc. Despite our model's simplifying assumptions, this study remains the only evidence of the possible regulation of $\mathrm{K}^{+}$channel activity at the IS by the ionic microenvironment.

In conclusion, the modeled $\mathrm{K}^{+}$accumulation in the IS cleft provides a possible explanation to why the rise in $\left[\mathrm{Ca}^{2+}\right]_{i}$ is reduced after IS formation. This study shows the importance of considering the activation state of the $\mathrm{T}$ cell, the ionic microenvironment and the $\mathrm{K}^{+}$channel spatial arrangement as a potential modulator of $\mathrm{T}$ cell function, but does not rule out the possibility that other cellular events such as protein phosphorylation or $\mathrm{Ca}^{2+}$ microdomains also occur at the IS ultimately affecting $\mathrm{K}^{+}$currents and $\left[\mathrm{Ca}^{2+}\right]_{\mathrm{i}}$. The utility of this model extends beyond its investigation of $\mathrm{K}^{+}$accumulation at the IS, however, because it provides a basic framework for making quantitative predictions of $\mathrm{T}$ cell membrane currents and $\left[\mathrm{Ca}^{2+}\right]_{\mathrm{i}}$. By altering model parameters or adding in new complexities, this model could offer predictions or confirmations about $\mathrm{T}$ cell function in a variety of circumstances. Ultimately, 
further theoretical and experimental investigations into the exact processes driving the IS physiology will be crucial in unlocking the ionic mechanisms of $\mathrm{T}$ cell activation.

\section{Highlights}

We model how extracellular $\mathrm{K}^{+}$accumulation in the immunological synapse affects $\mathrm{T}$ cell ionic currents. > Increased extracellular $\mathrm{K}^{+}$can decrease $\mathrm{T}$ cell $\mathrm{Ca}^{2+}$ influx. > The decreased $\mathrm{Ca}^{2+}$ influx is most prominent in activated $\mathrm{T}$ cells.

\section{Acknowledgments}

This project was supported by NIH grants CA095286-06 and AI083076-01, and AHA 0855457D.

\section{References}

Anton van der Merwe P, Davis SJ, Shaw AS, Dustin ML. Cytoskeletal polarization and redistribution of cell-surface molecules during T cell antigen recognition. Semin Immunol. 2000; 12:5-21. [PubMed: 10723794]

Bautista DM, Lewis RS. Modulation of plasma membrane calcium-ATPase activity by local calcium microdomains near CRAC channels in human T cells. J Physiol. 2004; 556:805-817. [PubMed: 14966303]

Borst JG, Sakmann B. Depletion of calcium in the synaptic cleft of a calyx-type synapse in the rat brainstem. J Physiol. 1999; 521(Pt 1):123-133. [PubMed: 10562339]

Bowlby MR, Fadool DA, Holmes TC, Levitan IB. Modulation of the Kv1.3 potassium channel by receptor tyrosine kinases. J Gen Physiol. 1997; 110:601-610. [PubMed: 9348331]

Burroughs NJ, Lazic Z, van der Merwe PA. Ligand detection and discrimination by spatial relocalization: A kinase-phosphatase segregation model of TCR activation. Biophys J. 2006; 91:1619-1629. [PubMed: 16751250]

Cahalan MD, Chandy KG. The functional network of ion channels in T lymphocytes. Immunol Rev. 2009; 231:59-87. [PubMed: 19754890]

Cahalan MD, Chandy KG, DeCoursey TE, Gupta S. A voltage-gated potassium channel in human T lymphocytes. J Physiol. 1985; 358:197-237. [PubMed: 2580081]

Cai YC, Douglass J. In vivo and in vitro phosphorylation of the T lymphocyte type $\mathrm{n}$ (Kv1.3) potassium channel. J Biol Chem. 1993; 268:23720-23727. [PubMed: 8226897]

Cemerski S, Shaw A. Immune synapses in T-cell activation. Curr Opin Immunol. 2006; 18:298-304. [PubMed: 16603343]

Cemerski S, Das J, Giurisato E, Markiewicz MA, Allen PM, Chakraborty AK, Shaw AS. The balance between $\mathrm{T}$ cell receptor signaling and degradation at the center of the immunological synapse is determined by antigen quality. Immunity. 2008; 29:414-422. [PubMed: 18760640]

Donnadieu E, Bismuth G, Trautmann A. Calcium fluxes in T lymphocytes. J Biol Chem. 1992; 267:25864-25872. [PubMed: 1464601]

Dushek O, Coombs D. Analysis of serial engagement and peptide-MHC transport in T cell receptor microclusters. Biophys J. 2008; 94:3447-3460. [PubMed: 18227132]

Dustin ML, Chan AC. Signaling takes shape in the immune system. Cell. 2000; 103:283-294. [PubMed: 11057901]

Egelman DM, Montague PR. Calcium dynamics in the extracellular space of mammalian neural tissue. Biophys J. 1999; 76:1856-1867. [PubMed: 10096884]

Fadool DA. Tyrosine phosphorylation downregulates a potassium current in rat olfactory bulb neurons and a cloned Kv1.3 channel. Ann N Y Acad Sci. 1998; 855:529-532. [PubMed: 9929647]

Fomina AF, Fanger CM, Kozak JA, Cahalan MD. Single channel properties and regulated expression of $\mathrm{Ca}(2+)$ release-activated $\mathrm{Ca}(2+)(\mathrm{CRAC})$ channels in human T cells. J Cell Biol. 2000; 150:1435-1444. [PubMed: 10995447] 
Freiberg BA, Kupfer H, Maslanik W, Delli J, Kappler J, Zaller DM, Kupfer A. Staging and resetting T cell activation in SMACs. Nat Immunol. 2002; 3:911-917. [PubMed: 12244310]

Galush WJ, Nye JA, Groves JT. Quantitative fluorescence microscopy using supported lipid bilayer standards. Biophys J. 2008; 95:2512-2519. [PubMed: 18515392]

Grakoui A, Bromley SK, Sumen C, Davis MM, Shaw AS, Allen PM, Dustin ML. The immunological synapse: a molecular machine controlling T cell activation. Science. 1999; 285:221-227. [PubMed: 10398592]

Grissmer S, Nguyen AN, Cahalan MD. Calcium-activated potassium channels in resting and activated human T lymphocytes. Expression levels, calcium dependence, ion selectivity, and pharmacology. J Gen Physiol. 1993; 102:601-630. [PubMed: 7505804]

Hajdu P, Varga Z, Pieri C, Panyi G, Gaspar R Jr. Cholesterol modifies the gating of Kv1.3 in human T lymphocytes. Pflugers Arch. 2003; 445:674-682. [PubMed: 12632187]

Hodgkin AL, Huxley AF. A quantitative description of membrane current and its application to conduction and excitation in nerve. J Physiol. 1952; 117:500-544. [PubMed: 12991237]

Holmes TC, Fadool DA, Levitan IB. Tyrosine phosphorylation of the Kv1.3 potassium channel. J Neurosci. 1996; 16:1581-1590. [PubMed: 8774427]

Hori S, Collette A, Demengeot J, Stewart J. A new statistical method for quantitative analyses: application to the precise quantification of T cell receptor repertoires. J Immunol Methods. 2002; 268:159-170. [PubMed: 12215384]

Hoth M, Button DC, Lewis RS. Mitochondrial control of calcium-channel gating: a mechanism for sustained signaling and transcriptional activation in T lymphocytes. Proc Natl Acad Sci U S A. 2000; 97:10607-10612. [PubMed: 10973476]

Kargacin GJ. Calcium signaling in restricted diffusion spaces. Biophys J. 1994; 67:262-272. [PubMed: 7918994]

Kesten, $H$. The critical probability of bond percolation on the square lattice equals $1 / 2$, Communications in Mathematical Physics. Vol. Vol. 74. Heidelberg: Springer Berlin; 1980. p. 41-59.

Koo GC, Blake JT, Talento A, Nguyen M, Lin S, Sirotina A, Shah K, Mulvany K, Hora D Jr, Cunningham P, Wunderler DL, McManus OB, Slaughter R, Bugianesi R, Felix J, Garcia M, Williamson J, Kaczorowski G, Sigal NH, Springer MS, Feeney W. Blockade of the voltage-gated potassium channel Kv1.3 inhibits immune responses in vivo. J Immunol. 1997; 158:5120-5128. [PubMed: 9164927]

Krummel MF, Cahalan MD. The immunological synapse: a dynamic platform for local signaling. $\mathrm{J}$ Clin Immunol. 2010; 30:364-372. [PubMed: 20390326]

Kummerow C, Junker C, Kruse K, Rieger H, Quintana A, Hoth M. The immunological synapse controls local and global calcium signals in T lymphocytes. Immunol Rev. 2009; 231:132-147. [PubMed: 19754894]

Levy DI, Deutsch C. A voltage-dependent role for K+ in recovery from C-type inactivation. Biophys J. 1996a; 71:3157-3166. [PubMed: 8968586]

Levy DI, Deutsch C. Recovery from C-type inactivation is modulated by extracellular potassium. Biophys J. 1996b; 70:798-805. [PubMed: 8789096]

Lewis RS. Calcium signaling mechanisms in T lymphocytes. Annu Rev Immunol. 2001; 19:497-521. [PubMed: 11244045]

Lewis RS, Cahalan MD. Mitogen-induced oscillations of cytosolic Ca2+ and transmembrane Ca2+ current in human leukemic T cells. Cell Regul. 1989; 1:99-112. [PubMed: 2519622]

Lioudyno MI, Kozak JA, Penna A, Safrina O, Zhang SL, Sen D, Roos J, Stauderman KA, Cahalan MD. Orai1 and STIM1 move to the immunological synapse and are up-regulated during T cell activation. Proc Natl Acad Sci U S A. 2008; 105:2011-2016. [PubMed: 18250319]

Luik RM, Wang B, Prakriya M, Wu MM, Lewis RS. Oligomerization of STIM1 couples ER calcium depletion to CRAC channel activation. Nature. 2008; 454:538-542. [PubMed: 18596693]

Monks CR, Freiberg BA, Kupfer H, Sciaky N, Kupfer A. Three-dimensional segregation of supramolecular activation clusters in T cells. Nature. 1998; 395:82-86. [PubMed: 9738502]

Mossman KD, Campi G, Groves JT, Dustin ML. Altered TCR signaling from geometrically repatterned immunological synapses. Science. 2005; 310:1191-1193. [PubMed: 16293763] 
Nicolaou SA, Neumeier L, Peng Y, Devor DC, Conforti L. The Ca(2+)- activated $\mathrm{K}(+)$ channel KCa3.1 compartmentalizes in the immunological synapse of human T lymphocytes. Am J Physiol Cell Physiol. 2007a; 292:C1431-C1439. [PubMed: 17151145]

Nicolaou SA, Neumeier L, Steckly A, Kucher V, Takimoto K, Conforti L. Localization of Kv1.3 channels in the immunological synapse modulates the calcium response to antigen stimulation in $\mathrm{T}$ lymphocytes. J Immunol. 2009; 183:6296-6302. [PubMed: 19841189]

Nicolaou SA, Szigligeti P, Neumeier L, Lee SM, Duncan HJ, Kant SK, Mongey AB, Filipovich AH, Conforti L. Altered dynamics of Kv1.3 channel compartmentalization in the immunological synapse in systemic lupus erythematosus. J Immunol. 2007b; 179:346-356. [PubMed: 17579055]

Nicolaou SA, Neumeier L, Takimoto K, Lee SM, Duncan HJ, Kant SK, Mongey AB, Filipovich AH, Conforti L. Differential calcium signaling and Kv1.3 trafficking to the immunological synapse in systemic lupus erythematosus. Cell Calcium. 2010; 47:19-28. [PubMed: 19959227]

Pahapill PA, Schlichter LC. Modulation of potassium channels in human T lymphocytes: effects of temperature. J Physiol. 1990; 422:103-126. [PubMed: 2352174]

Palti Y, Gold R, Stampfli R. Diffusion of ions in myelinated nerve fibers. Biophys J. 1979; 25:17-31. [PubMed: 318061]

Panyi G, Varga Z, Gaspar R. Ion channels and lymphocyte activation. Immunol Lett. 2004a; 92:55-66. [PubMed: 15081528]

Panyi G, Vamosi G, Bacso Z, Bagdany M, Bodnar A, Varga Z, Gaspar R, Matyus L, Damjanovich S. Kv1.3 potassium channels are localized in the immunological synapse formed between cytotoxic and target cells. Proc Natl Acad Sci U S A. 2004b; 101:1285-1290. [PubMed: 14745040]

Panyi G, Bagdany M, Bodnar A, Vamosi G, Szentesi G, Jenei A, Matyus L, Varga S, Waldmann TA, Gaspar R, Damjanovich S. Colocalization and nonrandom distribution of Kv1.3 potassium channels and CD3 molecules in the plasma membrane of human T lymphocytes. Proc Natl Acad Sci U S A. 2003; 100:2592-2597. [PubMed: 12604782]

Poulopoulou C, Papadopoulou-Daifoti Z, Hatzimanolis A, Fragiadaki K, Polissidis A, Anderzanova E, Davaki P, Katsiari CG, Sfikakis PP. Glutamate levels and activity of the T cell voltage-gated potassium Kv1.3 channel in patients with systemic lupus erythematosus. Arthritis Rheum. 2008; 58:1445-1450. [PubMed: 18438846]

Prakriya M, Lewis RS. CRAC channels: activation, permeation, and the search for a molecular identity. Cell Calcium. 2003; 33:311-321. [PubMed: 12765678]

Quintana A, Griesemer D, Schwarz EC, Hoth M. Calcium-dependent activation of T-lymphocytes. Pflugers Arch. 2005; 450:1-12. [PubMed: 15806400]

Rader RK, Kahn LE, Anderson GD, Martin CL, Chinn KS, Gregory SA. T cell activation is regulated by voltage-dependent and calcium-activated potassium channels. J Immunol. 1996; 156:14251430. [PubMed: 8568243]

Raychaudhuri S, Chakraborty AK, Kardar M. Effective membrane model of the immunological synapse. Phys Rev Lett. 2003; 91:208101. [PubMed: 14683399]

Robbins JR, Lee SM, Filipovich AH, Szigligeti P, Neumeier L, Petrovic M, Conforti L. Hypoxia modulates early events in $\mathrm{T}$ cell receptor-mediated activation in human T lymphocytes via Kv1.3 channels. J Physiol. 2005; 564:131-143. [PubMed: 15677684]

Rusakov DA, Fine A. Extracellular Ca2+ depletion contributes to fast activity-dependent modulation of synaptic transmission in the brain. Neuron. 2003; 37:287-297. [PubMed: 12546823]

Sykova E, Nicholson C. Diffusion in brain extracellular space. Physiol Rev. 2008; 88:1277-1340. [PubMed: 18923183]

Szigligeti P, Neumeier L, Duke E, Chougnet C, Takimoto K, Lee SM, Filipovich AH, Conforti L. Signalling during hypoxia in human T lymphocytes--critical role of the src protein tyrosine kinase p56Lck in the O2 sensitivity of Kv1.3 channels. J Physiol. 2006; 573:357-370. [PubMed: 16600997]

Thomas RC. The plasma membrane calcium ATPase (PMCA) of neurones is electroneutral and exchanges $2 \mathrm{H}+$ for each Ca2+ or Ba2+ ion extruded. J Physiol. 2009; 587:315-327. [PubMed: 19064619] 
Toth A, Szilagyi O, Krasznai Z, Panyi G, Hajdu P. Functional consequences of Kv1.3 ion channel rearrangement into the immunological synapse. Immunol Lett. 2009; 125:15-21. [PubMed: 19477198]

Treherne JE, Lane NJ, Moreton RB, Pichon Y. A quantitative study of potassium movements in the central nervous system of Periplaneta americana. J Exp Biol. 1970; 53:109-136. [PubMed: 5478669]

Vassilev PM, Mitchel J, Vassilev M, Kanazirska M, Brown EM. Assessment of frequency-dependent alterations in the level of extracellular Ca2+ in the synaptic cleft. Biophys J. 1997; 72:2103-2116. [PubMed: 9129812]

Verheugen JA, Vijverberg HP. Intracellular Ca2+ oscillations and membrane potential fluctuations in intact human T lymphocytes: role of K+ channels in Ca2+ signaling. Cell Calcium. 1995; 17:287300. [PubMed: 7664316]

Verheugen JA, Vijverberg HP, Oortgiesen M, Cahalan MD. Voltage-gated and $\mathrm{Ca}(2+)$-activated $\mathrm{K}+$ channels in intact human T lymphocytes. Noninvasive measurements of membrane currents, membrane potential, and intracellular calcium. J Gen Physiol. 1995; 105:765-794. [PubMed: 7561743]

Weikl TR, Lipowsky R. Pattern formation during T-cell adhesion. Biophys J. 2004; 87:3665-3678. [PubMed: 15377531]

Willemsen OH, Snel MM, van der Werf KO, de Grooth BG, Greve J, Hinterdorfer P, Gruber HJ, Schindler H, van Kooyk Y, Figdor CG. Simultaneous height and adhesion imaging of antibodyantigen interactions by atomic force microscopy. Biophys J. 1998; 75:2220-2228. [PubMed: 9788917]

Wulff H, Calabresi PA, Allie R, Yun S, Pennington M, Beeton C, Chandy KG. The voltage-gated $\mathrm{Kv1.3} \mathrm{K(+)} \mathrm{channel} \mathrm{in} \mathrm{effector} \mathrm{memory} \mathrm{T} \mathrm{cells} \mathrm{as} \mathrm{new} \mathrm{target} \mathrm{for} \mathrm{MS.} \mathrm{J} \mathrm{Clin} \mathrm{Invest.} \mathrm{2003;}$ 111:1703-1713. [PubMed: 12782673]

Zaniboni M, Swietach P, Rossini A, Yamamoto T, Spitzer KW, Vaughan-Jones RD. Intracellular proton mobility and buffering power in cardiac ventricular myocytes from rat, rabbit, and guinea pig. Am J Physiol Heart Circ Physiol. 2003; 285:H1236-H1246. [PubMed: 12750065]

Zweifach A, Lewis RS. Mitogen-regulated Ca2+ current of T lymphocytes is activated by depletion of intracellular Ca2+ stores. Proc Natl Acad Sci U S A. 1993; 90:6295-6299. [PubMed: 8392195] 
A

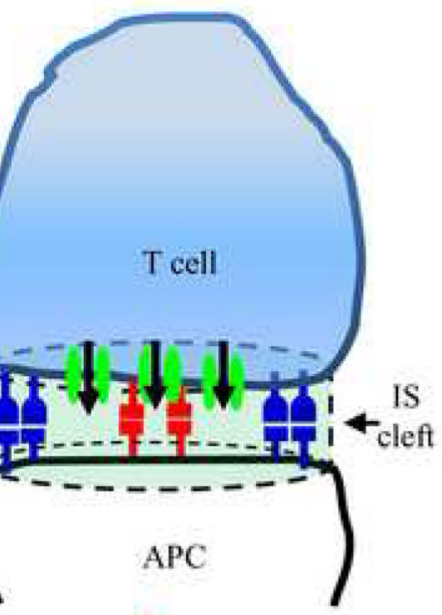

LFA-1

ICAM
B

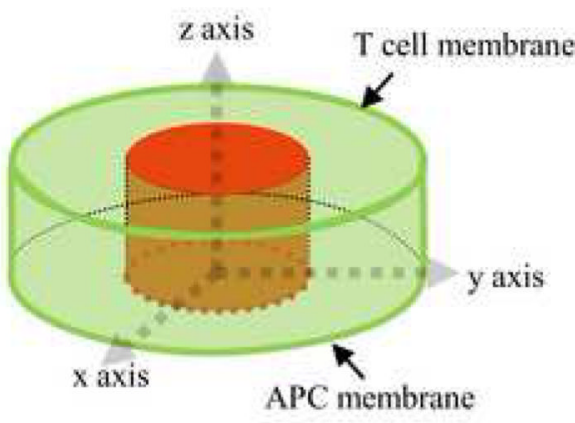

C

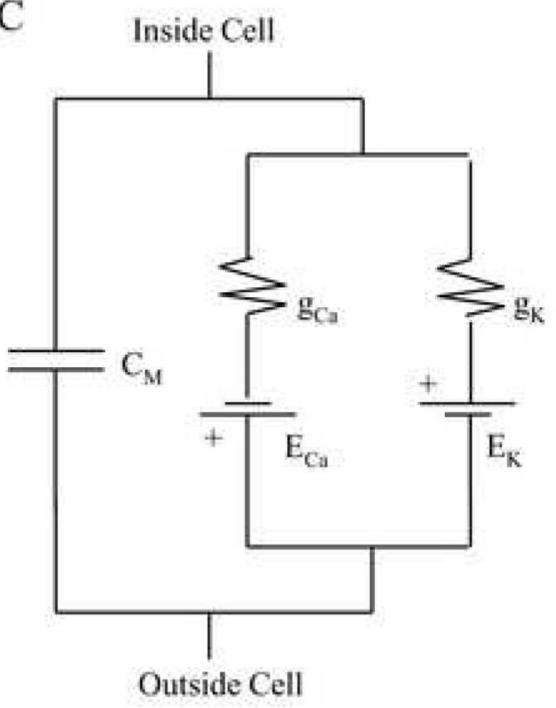

FIGURE 1.

Schematic representation of the immune synaptic cleft and electrical circuit of the $T$ cell membrane. (A) IS cleft between a T cell and an APC with appropriate binding molecules. $\mathrm{K}^{+}$channels are shown in green, the TCR/major histocompatibility complex (MHC) in red and LFA-1/inter-cellular adhesion molecule (ICAM) in blue. The IS cleft is defined by a dashed green shade cylinder between the two cells and shown enlarged in (B) with normal Cartesian coordinates $(x, y, z$ axis) defined. The red region in (B) denotes the central IS cleft volume localized at the cSMAC area. (C) T cell membrane electrical circuit with $\mathrm{g}_{\mathrm{K}}$ the $\mathrm{K}^{+}$ conductance through $\mathrm{Kv} 1.3$ and $\mathrm{KCa} 3.1$ channels, $\mathrm{g}_{\mathrm{Ca}}$ the $\mathrm{Ca}^{2+}$ conductance through $\mathrm{CRAC}$ channels, $\mathrm{E}_{\mathrm{K}}$ the $\mathrm{K}^{+}$driving force and $\mathrm{E}_{\mathrm{Ca}}$ the $\mathrm{Ca}^{2+}$ driving force. 


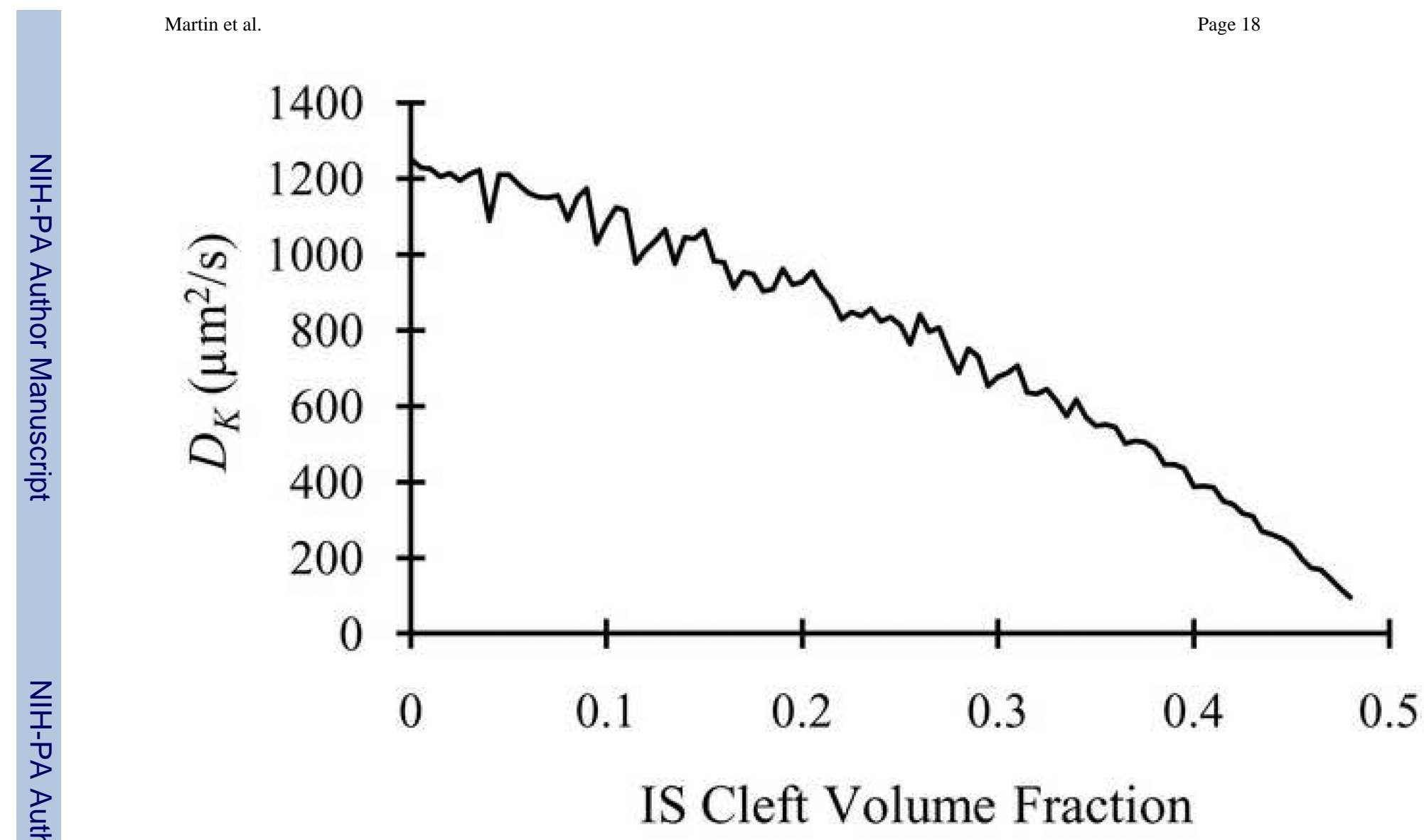

FIGURE 2.

Simulation results for $D_{K}$. Random walk results of $D_{K}$ reported in terms of $\%$ volume of the IS cleft occupied by intercellular proteins (denoted as IS Cleft Volume Fraction on the Xaxis). 
A

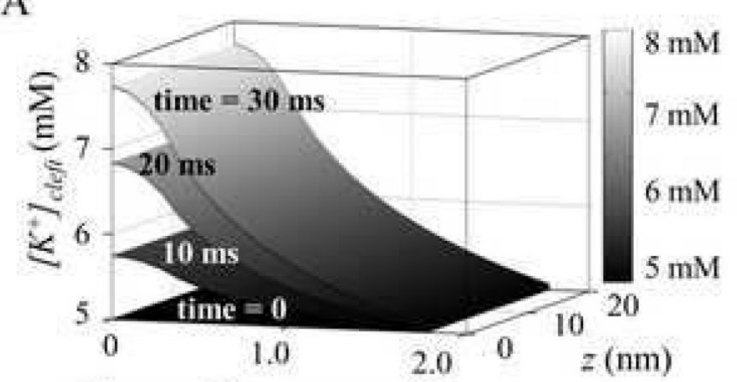

Distance from center of IS

cleft $(\mu \mathrm{m})$

B
Diffusion
Channels
Channels
Constant Clustered
Uniform
$\left[K^{+}\right]_{\text {clets }}$
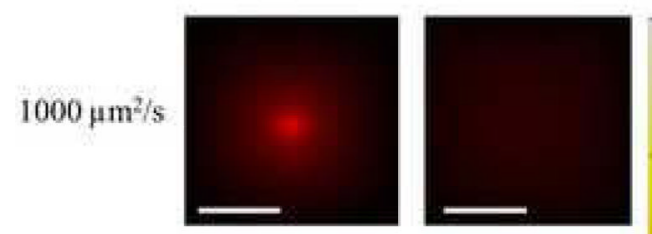

$10 \mathrm{mM}$

$9,0 \mathrm{mM}$
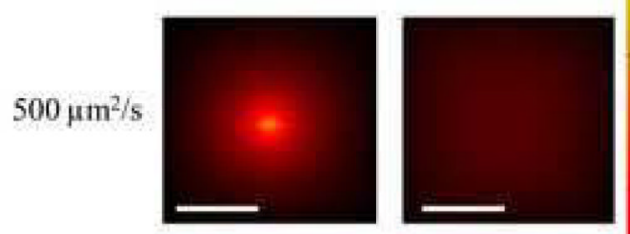

$8.0 \mathrm{mM}$
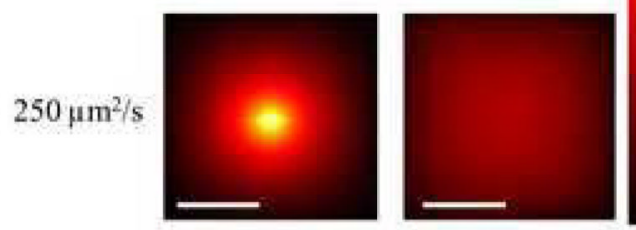

$7,0 \mathrm{mM}$

C

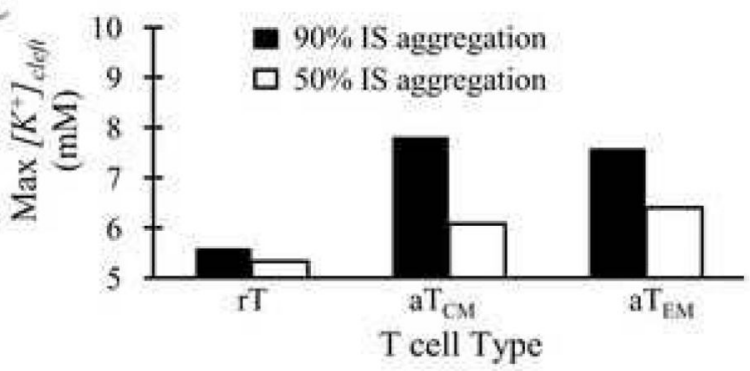

FIGURE 3.

Spatial dependence of $\left[\mathrm{K}^{+}\right]_{\text {cleft }}$ for different T cell types. (A) $\left[\mathrm{K}^{+}\right]_{\text {cleft }}$ is reported as it relates to the distance from the center of the IS cleft and the distance from the T cell membrane ( $z$ in Fig. 1B) at different times. The simulations reported were conducted in a aT $\mathrm{CM}_{\mathrm{M}}$ cell assuming a $D_{K}$ of $500 \mu \mathrm{m}^{2} / \mathrm{s}, 90 \% \mathrm{~K}^{+}$channel IS accumulation, and central clustering of $\mathrm{K}^{+}$channel at the IS. (B) $\left[\mathrm{K}^{+}\right]_{\text {cleft }}$ values as projected onto the xy-plane (as defined in Fig. 1B) for various $D_{K}$ and $\mathrm{K}^{+}$channel IS distributions when $90 \%$ of total $\mathrm{K}^{+}$ channels were located at the IS in an aT $\mathrm{T}_{\mathrm{CM}}$ cell at $t=100 \mathrm{~s}$. The white scale bar represents $\sim 1.80 \mu \mathrm{m}$, and the range of $\left[K^{+}\right]_{\text {cleft }}$ was pseudocolored using a scale shown in the right. (C) 
The maximum $\left[\mathrm{K}^{+}\right]_{\text {cleft }}$ for different $\mathrm{T}$ cell types when $\mathrm{K}^{+}$channels are centrally clustered in the IS with either 50 or $90 \% \mathrm{~K}^{+}$channel IS aggregation at a $D_{K}$ of $500 \mu \mathrm{m}^{2} / \mathrm{s}$. 
A

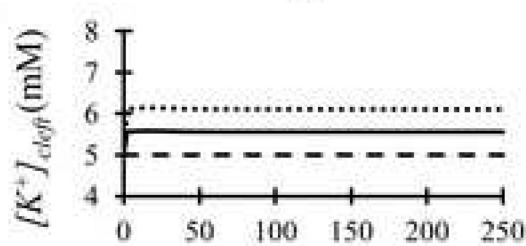

Time (s)

B

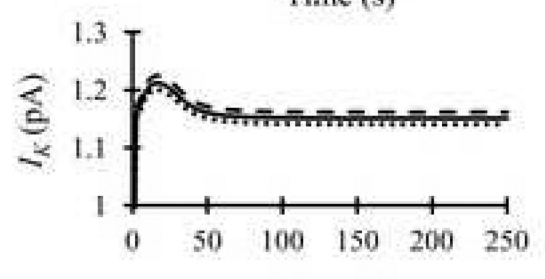

C

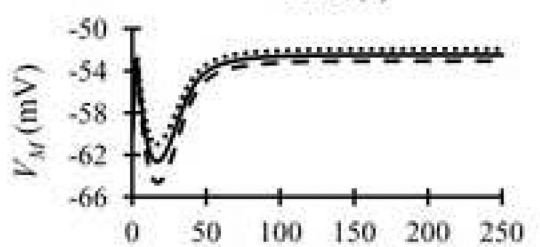

D

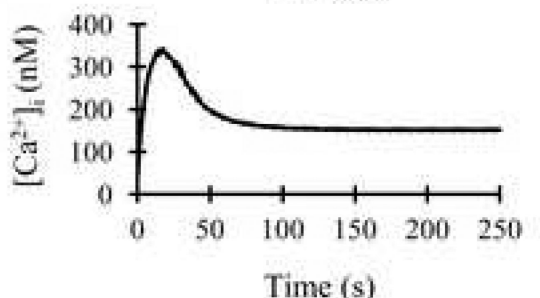

Time (s)

- - - No $\mathrm{K}^{+}$channel aggregation at is

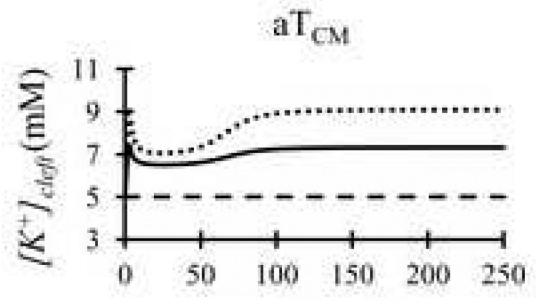

Time (s)
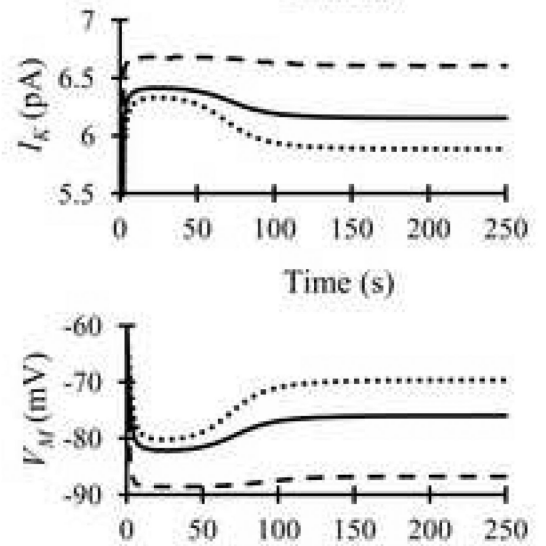

Time (s)

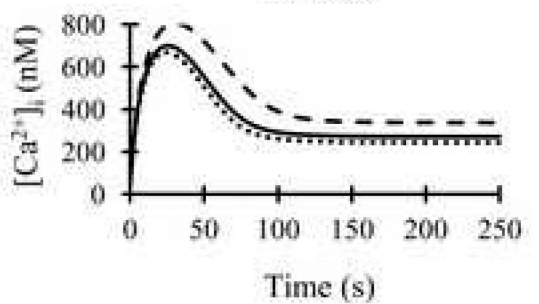

$\mathrm{K}^{+}$channel aggregation at IS with $D_{K}=500 \mathrm{um}^{2} / \mathrm{s}$

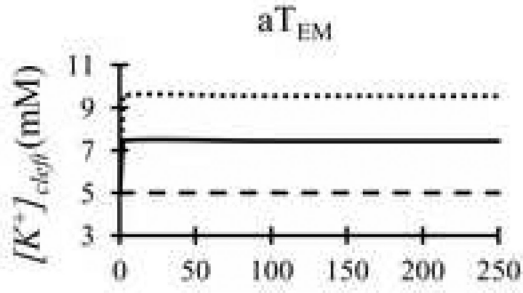

Time (s)

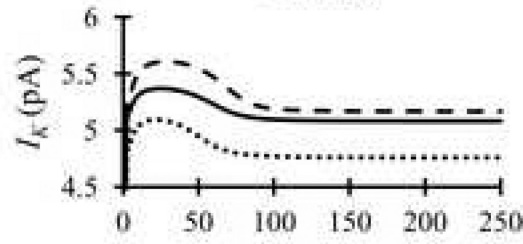

Time (s)

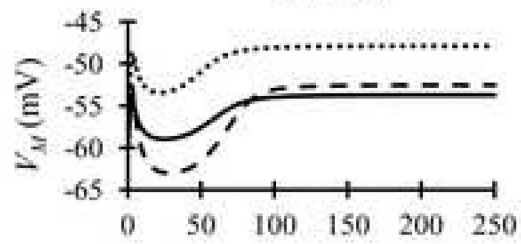

Time (s)

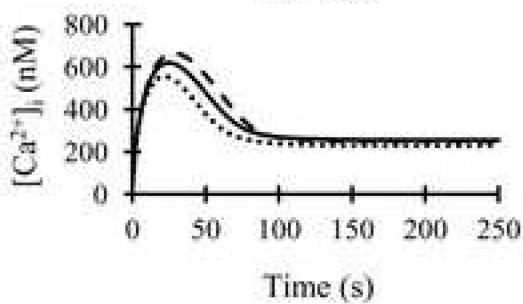

$\mathrm{K}^{+}$channel aggregation at IS with $D_{K}=250 \mu \mathrm{m}^{2} / \mathrm{s}$

FIGURE 4.

Time dependent changes in $\left[K^{+}\right]_{c l e f t}, I_{K}, V_{M}$, and $\left[\mathrm{Ca}^{2+}\right]_{\mathrm{i}}$ due to IS $\mathrm{K}^{+}$channel aggregation. Simulations with $D_{K}$ of $500 \mu \mathrm{m}^{2} / \mathrm{s}$ (solid line) and $250 \mu \mathrm{m}^{2} / \mathrm{s}$ (dotted line) in a model with IS $\mathrm{K}^{+}$channel aggregation are compared to no IS $\mathrm{K}^{+}$channel aggregation (dashed line) in different $\mathrm{T}$ cell types. All simulations with IS $\mathrm{K}^{+}$channel aggregation were performed with $90 \% \mathrm{~K}^{+}$channel aggregation and central clustering of $\mathrm{K}^{+}$channels. We assumed the following initial conditions: the $\left[\mathrm{K}^{+}\right]_{\text {cleft }}$ was assumed to be $5 \mathrm{mM},\left[\mathrm{Ca}^{2+}\right]_{\mathrm{i}}$ was assumed to be $50 \mathrm{nM}, V_{M}$ was assumed to be $-60 \mathrm{mV}$, CRAC channels were assumed to open at $t=0$ in response to simulated $\mathrm{T}$ cell stimulation by an $\mathrm{APC}$, and $\mathrm{K}^{+}$channels were assumed to be centrally located at the IS at the initial condition except for the simulation with no IS $\mathrm{K}^{+}$ channel aggregation where channels were assumed to be uniformly distributed throughout the plasma membrane. (A) Time dependence of $\left[K^{+}\right]_{\text {cleft }}(\mathrm{B}-\mathrm{D})$ Changes in $I_{K}(\mathrm{~B}), V_{M}(\mathrm{C})$ and $\left[\mathrm{Ca}^{2+}\right]_{\mathrm{i}}(\mathrm{D})$. 


\section{Table I}

List of model parameters.

\begin{tabular}{|c|c|c|c|}
\hline Parameter & $\begin{array}{l}\text { Resting } \mathrm{T} \text { cell } \\
\text { values }\end{array}$ & $\begin{array}{l}\text { Activated T cell } \\
\text { values }\end{array}$ & Description \\
\hline$C_{M}$ & $1 \mathrm{pF}$ & $3 \mathrm{pF}$ & Cell membrane capacitance (Wulff et al., 2003) \\
\hline$K$ & $0.04 \mathrm{~s}^{-1}$ & $0.04 \mathrm{~s}^{-1}$ & PMCA modulation time constant (Bautista and Lewis, 2004) \\
\hline$W_{\max }$ & $3.6 \times 10^{6} \mathrm{ions} / \mathrm{s}$ & $22 \times 10^{6} \mathrm{ions} / \mathrm{s}$ & Modulated max PMCA flux \\
\hline$U_{\max }$ & $1.1 \times 10^{6} \mathrm{ions} / \mathrm{s}$ & $6.6 \times 10^{6} \mathrm{ions} / \mathrm{s}$ & Adjustment of $V_{\max }$ for unmodulated PMCA pump \\
\hline$K_{m}$ & $140 \mathrm{nM}$ & $140 \mathrm{nM}$ & Modulated PMCA $\left[\mathrm{Ca}^{2+}\right]_{\mathrm{i}}$ at half of $V_{\max }$ (Bautista and Lewis, 2004) \\
\hline$U_{m}$ & $303 \mathrm{nM}$ & $303 \mathrm{nM}$ & Adjustment of $K_{m}$ for unmodulated PMCA pump (Bautista and Lewis, 2004) \\
\hline$\beta$ & 125 & 125 & Dimensionless cytoplasmic $\mathrm{Ca}^{2+}$ buffering capacity (Donnadieu et al., 1992) \\
\hline Volume & $0.5 \mathrm{pL}$ & $2.0 \mathrm{pL}$ & Cytoplasmic volume of T cell (Grakoui et al., 1999) \\
\hline$g K_{v 1.3}$ & $11 \mathrm{pS}$ & $11 \mathrm{pS}$ & Single channel conductance of Kv1.3 channels (Szigligeti et al., 2006) \\
\hline$g K_{C a 3.1}$ & $11 \mathrm{pS}$ & $11 \mathrm{pS}$ & $\begin{array}{l}\text { Single channel conductance of KCa3.1 channels (Grissmer et al., 1993; Robbins et al., } \\
\text { 2005) }\end{array}$ \\
\hline$K_{C a}$ & $400 \mathrm{nM}$ & $400 \mathrm{nM}$ & {$\left[\mathrm{Ca}^{2+}\right]_{\mathrm{i}}$ at half maximum $\mathrm{KCa} 3.1$ activation (Grissmer et al., 1993) } \\
\hline$A$ & $-0.012 \mathrm{pA} / \mathrm{mV}$ & $-0.090 \mathrm{pA} / \mathrm{mV}$ & $\begin{array}{l}\text { Empirical linear constant for CRAC current (Lewis and Cahalan, 1989; Lioudyno et al., } \\
\text { 2008; Zweifach and Lewis, 1993) }\end{array}$ \\
\hline$B$ & $1.7 \mathrm{pA}$ & $13 \mathrm{pA}$ & $\begin{array}{l}\text { Empirical linear constant for CRAC current (Lewis and Cahalan, 1989; Lioudyno et al., } \\
\text { 2008; Zweifach and Lewis, 1993) }\end{array}$ \\
\hline$\left[K^{+}\right]_{i}$ & $140 \mathrm{mM}$ & $140 \mathrm{mM}$ & Intracellular $\mathrm{K}^{+}$concentration \\
\hline
\end{tabular}


Table II

Number of $\mathrm{K}^{+}$channels by $\mathrm{T}$ cell type.

\begin{tabular}{lll}
\hline T cell type & $\begin{array}{l}\text { Number of } \\
\text { Kv1.3 Channels }\end{array}$ & $\begin{array}{l}\text { Number of KCa3.1 } \\
\text { channels }\end{array}$ \\
\hline $\mathrm{rT}$ & 400 & 10 \\
$\mathrm{aT}_{\mathrm{CM}}$ & 500 & 500 \\
$\mathrm{aT}_{\mathrm{EM}}$ & 1500 & 20 \\
\hline
\end{tabular}

